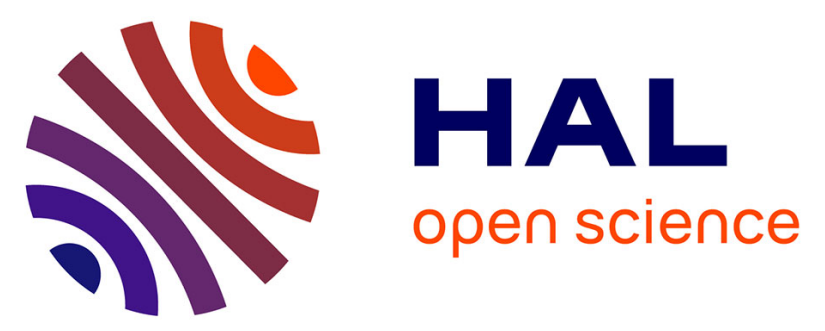

\title{
Trace elements in a Mediterranean scorpaenid fish: Bioaccumulation processes and spatial variations
}

Melanie Ourgaud, Sandrine Ruitton, Hugo Bourgogne, Paco Bustamante, Carine Churlaud, Gaël Guillou, Benoit Lebreton, Mireille Harmelin-Vivien

\section{- To cite this version:}

Melanie Ourgaud, Sandrine Ruitton, Hugo Bourgogne, Paco Bustamante, Carine Churlaud, et al.. Trace elements in a Mediterranean scorpaenid fish: Bioaccumulation processes and spatial variations. Progress in Oceanography, 2018, 163, pp.184-195. 10.1016/j.pocean.2017.11.008 . hal-02023571

\section{HAL Id: hal-02023571 https://hal.science/hal-02023571}

Submitted on 18 Feb 2019

HAL is a multi-disciplinary open access archive for the deposit and dissemination of scientific research documents, whether they are published or not. The documents may come from teaching and research institutions in France or abroad, or from public or private research centers.
L'archive ouverte pluridisciplinaire HAL, est destinée au dépôt et à la diffusion de documents scientifiques de niveau recherche, publiés ou non, émanant des établissements d'enseignement et de recherche français ou étrangers, des laboratoires publics ou privés. 


\title{
Ourgaud M., Ruitton S., Bourgogne H., Bustamante P., Churlaud C., Guillou G., Lebreton B., Harmelin-Vivien M. 2018. Trace elements in a Mediterranean scorpaenid fish: bioaccumulation processes and spatial variations. Progress in Oceanography, 163: 184-195. https://doi.org/10.1016/j.pocean.2017.11.008
}

\section{Trace elements in a Mediterranean scorpaenid fish: Bioaccumulation processes and spatial variations}

\author{
Mélanie Ourgaud $^{\mathrm{a}, *}$, Sandrine Ruitton ${ }^{\mathrm{a}}$, Hugo Bourgogne ${ }^{\mathrm{a}}$, Paco Bustamante ${ }^{\mathrm{b}}$, Carine Churlaud ${ }^{\mathrm{b}}$, \\ Gaël Guillou ${ }^{\mathrm{b}}$, Benoît Lebreton ${ }^{\mathrm{b}}$, Mireille L. Harmelin-Vivien ${ }^{\mathrm{a}}$ \\ a Aix Marseille Univ, Université de Toulon, CNRS, IRD, Mediterranean Institute of Oceanography (MIO), UM 110, 13288 Marseille, France \\ ${ }^{\mathrm{b}}$ LIttoral ENvironnement et Sociétés (LIENSs), UMR 7266, CNRS-Université de La Rochelle, 2 rue Olympes de Gouges, 17000 La Rochelle, France
}

\section{A R T I C L E I N F O}

\section{Keywords:}

Trace elements

Bioaccumulation

Scorpaena porcus

Mediterranean Sea

\begin{abstract}
A B S T R A C T
The black scorpionfish Scorpaena porcus, a carnivorous sedentary species, was studied as an indicator of local trace element (TE) contamination of coastal fish species in the northwestern Mediterranean Sea. Fish were collected in seagrass meadows in winter 2012 at four sampling sites: three were located near Marseille, a highly urbanized and industrial area that is subjected to various types of contaminant inputs, and one was located near Hyères, a less urbanized area. Size, sex, age and diet of fish were determined before stable isotope and TE analyses. $\mathrm{C}$ and $\mathrm{N}$ isotopic compositions and concentrations of nine TEs (As, $\mathrm{Ba}, \mathrm{Cd}, \mathrm{Cu}, \mathrm{Cr}, \mathrm{T}-\mathrm{Hg}, \mathrm{Ni}, \mathrm{Pb}$, and $\mathrm{Zn}$ ) were determined in dorsal white muscle. Most TEs did not bioaccumulate in $S$. porcus, as no increase in TE concentrations with increasing size, age or trophic level of fish was evident. Total mercury (T-Hg) was the only element to bioaccumulate and biomagnify, displaying strong positive correlations of its concentration with age $(\mathrm{r}=0.88, \mathrm{p}<0.01)$, length $(\mathrm{r}=0.84, \mathrm{p}<0.01)$ and $\delta^{15} \mathrm{~N}$ value $(\mathrm{r}=0.68, \mathrm{p}<0.01)$. Compared with the reference site, higher concentrations of $\mathrm{As}, \mathrm{Ba}, \mathrm{Cd}, \mathrm{T}-\mathrm{Hg}, \mathrm{Pb}$, and $\mathrm{Zn}$ were recorded in fish collected at one or all of the Marseille site. In contrast, no difference was observed for $\mathrm{Cr}, \mathrm{Cu}$, and $\mathrm{Ni}$ concentrations with site. Spatial differences in TE concentrations in $S$. porcus were related to differences in isotopic composition and to the primary environmental characteristics and human activities prevailing at each site. Concentrations of $\mathrm{Cd}, \mathrm{T}-\mathrm{Hg}$ and $\mathrm{Pb}$ in fish muscle (priority substances for monitoring) were all below the maximum permitted European values.
\end{abstract}

\section{Introduction}

Coastal marine environments represent high value eco-socio-systems, but they are also discharge and accumulation areas of anthropogenic compounds, such as trace elements (TEs) (Matthai et al., 2002; Cobelo-García et al., 2004). Such chemical contamination leads to the alteration of marine ecosystems, with an impact at individual, species, population and community levels (Fleeger et al., 2003; Halpern et al., 2008; Tartu et al., 2013). The Mediterranean Sea being a semi-enclosed sea, it is predicted to be a particularly sensitive system to any change in its hydrographic conditions due to either climatic or anthropogenic forcings (Bethoux et al., 1999; The MERMEX Group, 2011). The biogeochemical cycling of TEs at the scale of the Mediterranean Sea is largely governed by atmospheric inputs and air-water exchanges (Migon et al., 2002; Heimbürger et al., 2010; The MERMEX Group, 2011). However, in coastal zones and on continental shelves, rivers, such as the Rhône River in the Gulf of Lions, constitute the main input of terrigenous dissolved organic carbon (DOC) (Sempéré et al., 2000) and particulate metals (Elbaz-Poulichet, 2005; Cathalot et al., 2013; Cossa et al., this issue). In addition, TE input sources include submarine volcanoes, cold seepages and sub-marine freshwater inflows, as well as inputs from large coastal cities, industries, effluents, runoff and marine traffic (Oursel et al., 2013).

Certain TEs have the capability to bioaccumulate within aquatic organisms from the environment because of their persistent nature, chemical speciation and bioavailability (MacDonald et al., 2002; Castro-González and Méndez-Armenta, 2008; The MERMEX Group, 2011, Vieira et al., 2011). Certain TEs have unknown functions in biological systems and are considered to be potentially toxic to organisms at low concentrations, such as barium (Ba), cadmium (Cd), total mercury (T-Hg) and lead (Pb) (Schroeder and Darrow, 1972; Velusamy et al., 2014). Other TEs are essential, such as arsenic (As), copper (Cu), chromium (Cr), nickel (Ni), and zinc (Zn), as they play a specific role in metabolism (Authman et al., 2012; Bosch et al., 2016) and are required 


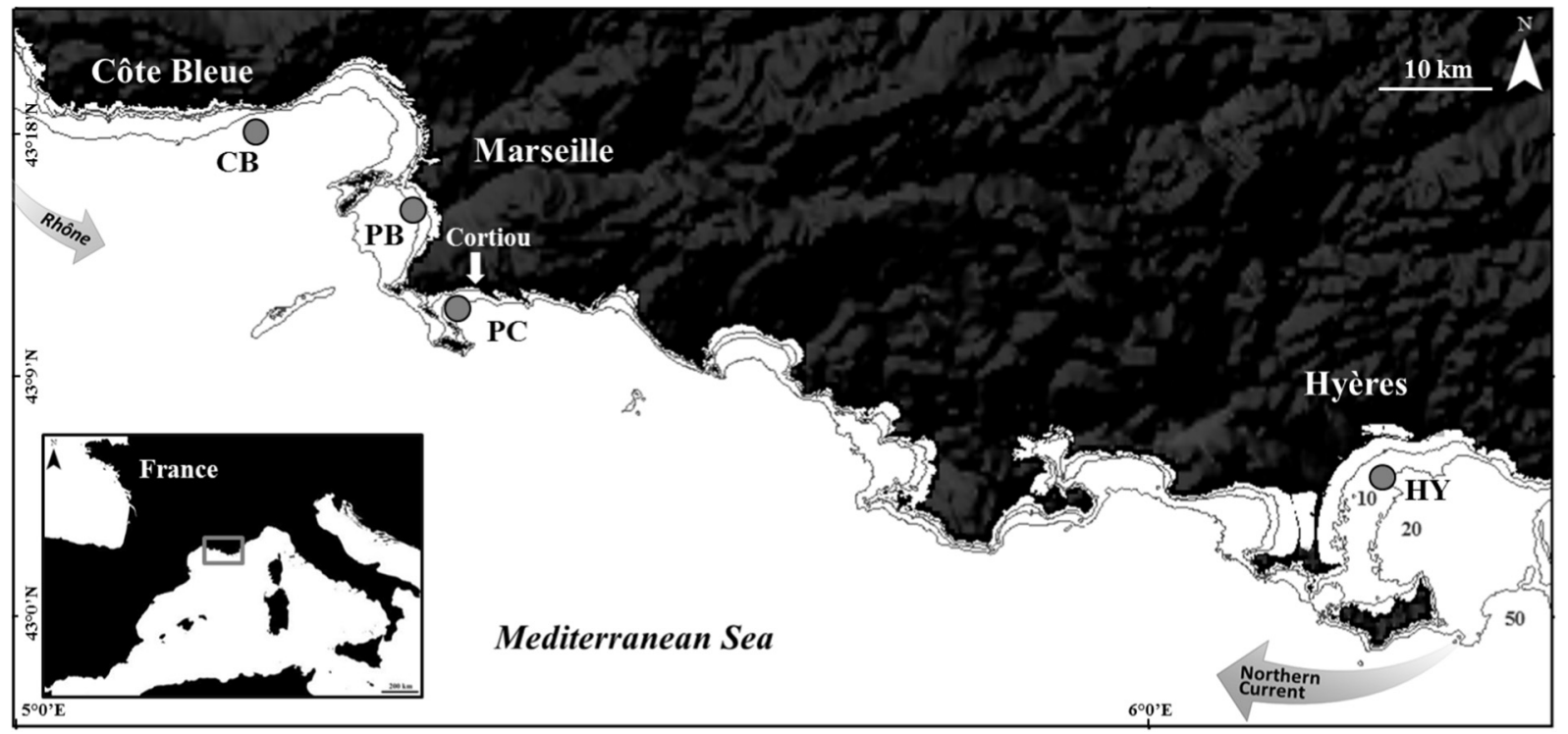

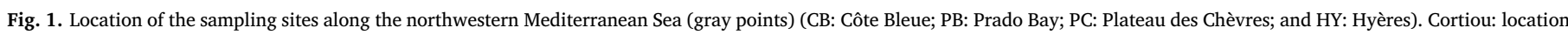
of Marseille sewage output. Bathymetric data from SHOM, 2010.

by living organisms in small concentrations to achieve a normal ontogenetic development (Merciai et al., 2014). However, essential TEs may also have toxic effects at elevated exposure levels (Wood, 2012; Vrhovnik et al., 2013). The sorption of TEs is affected by chemical (e.g., chemical speciation; Vrhovnik et al., 2013), environmental (e.g., pH, temperature and turbidity; Castro-González and Méndez-Armenta, 2008) and biological factors. Contaminants can bioaccumulate during the life of organisms (increases with size or age) and biomagnify with increasing trophic level, but different patterns are observed depending on the contaminant and the organism (Harmelin-Vivien et al., 2012). While the contamination of fish by TEs can come directly from the water through respiration or directly through the skin and membranes, the main way of TE inputs into fish is food through the consumption of contaminated prey (Hall et al., 1997). Bioaccumulation in fish is a complex process that depends on various biological parameters (species, size, age, sex, diet, trophic level and metabolism) (Castro-González and Méndez-Armenta, 2008; Harmelin-Vivien et al., 2012; Wood, 2012), and differs among tissues due to differences in TE absorption, detoxification and storage mechanisms (Has-Schön et al., 2006; Storelli, 2008; Metian et al, 2013). Contaminants, such as TEs, emerged as useful ecotracers of trophic patterns and environmental parameters when used in combination with other chemical tracers, such as $\mathrm{C}$ and $\mathrm{N}$ isotopic compositions (Dierking et al., 2009; Chouvelon et al., 2014; Cresson et al., 2014b, 2015b), as they provide complementary timeand space-integrated information on bioaccumulation events and trophic positions of fish in the food web.

Environmental monitoring programs for coastal ecosystems are developing in the Mediterranean Sea for providing scientific knowledge in the assessment of the health and sustainability of ecosystems (Tomasello et al., 2012; Copat et al., 2013; Miniero et al., 2014; Personnic et al., 2014; Naccari et al., 2015; Bonito et al., 2016). Studies carried out on TE bioconcentration and/or biomagnification in Mediterranean species investigated magnoliophytes (Pergent-Martini, 1998; Pergent and Pergent-Martini, 1999; Lafabrie et al., 2007, 2009), invertebrates (Perez et al., 2005; Lafabrie et al., 2007; Angeletti et al., 2014), and fish (Canli and Atli, 2003; Copat et al., 2012, 2013). However, most studies on fish concern continental shelf species and are focused on $\mathrm{Hg}$ contamination (Harmelin-Vivien et al., 2009, 2012; Cossa et al., 2012; Cresson et al., 2014a, 2015a, 2015b). Thus, there is a lack of knowledge on TE concentrations in fish species living in coastal waters of the northwestern Mediterranean Sea (Uluozlu et al., 2007).

In France, the annual per capita fish consumption ranges from 30 to
$60 \mathrm{~kg}$ (FAO, 2012; Vieira et al., 2015) and seafood has always been an important part of the diet of Mediterranean populations (Faget, 2009). Given the potential deleterious effects to human health related to the consumption of contaminated fish (Domingo et al., 2007; Martorell et al., 2011; Vieira et al., 2011), it is crucial to better understand the processes of TE accumulation in Mediterranean coastal fishes and to evaluate the subsequent risk due to fish consumption. The black scorpionfish, Scorpaena porcus Linnaeus, 1758, while not the most consumed species, is largely used in traditional recipes (fish soup, fried scorpionfish fillets and the famous "bouillabaisse") and is a common component of local fisheries all year round (Leleu et al., 2014). This species is common in all of the Mediterranean Sea between 5 and $30 \mathrm{~m}$ depth, but may be occasionally recorded deeper. This a sedentary macrocarnivore living on rocky substrates and seagrass beds (HarmelinVivien et al., 1989). It plays an important role in the trophic functioning of these ecosystems, being one of the most common predators and accounting for $18-35 \%$ of the total fish biomass (Bell and HarmelinVivien 1982; Ourgaud et al., 2015). For these characteristics, S. porcus could be used as an indicator of TE contamination in Mediterranean coastal fish species.

Thus, the aim of the present study was to provide some baseline information on the concentration levels of different TEs (As, Ba, Cd, Cr, $\mathrm{Cu}, \mathrm{Ni}, \mathrm{T}-\mathrm{Hg}, \mathrm{Pb}$, and $\mathrm{Zn}$ ) susceptible to revealing anthropic influences in coastal marine fishes or being a threat to health security. For this purpose, S. porcus was collected from different locations subjected to different degrees of anthropic inputs. We used a multi-tracer approach (TEs, C and N stable isotopes, stomach contents and otolith analyses) and analyzed muscles that are the main portion of the fish eaten by consumers. The main questions addressed are (1) Did TE concentrations differ among sampling sites and were they related to differences in the biological parameters of fish or characteristics of the environment? (2) Were these differences similar for all TEs analyzed? (3) Could bioaccumulation and/or biomagnification processes be evident for some TEs? (4) Are TE concentrations recorded below European regulations for fish flesh commercialization?

\section{Materials and methods}

\subsection{Study area and sample preparation}

This study was carried out in Posidonia oceanica seagrass meadows in three sampling sites of the Bay of Marseille, in the vicinity of one of 
the largest cities on the Mediterranean Sea, and in one site of the Gulf of Hyères (HY), a less urbanized or industrialized area, considered as a reference site (Fig.1). The three Marseille sites were subjected to different anthropic and freshwater inputs: Côte Bleue (CB), located in the northern area of the bay and not directly influenced by Marseille urban sewage, but sporadically exposed to the influence of Rhône River waters (Petrenko et al., 2005); Prado Bay (PB), subjected to episodic inputs from the small coastal Huveaune River and to constant urban and harbor inputs; and Plateau des Chèvres (PC), located in the southern area of the bay close to the outlet of the Cortiou wastewater treatment plant, and thus directly exposed to nutrient-rich urban sewage (Bellan, 1970; Arfi et al., 2000).

Fish were sampled by fishermen operating a small beam trawl $(1.5 \times 0.5 \mathrm{~m}, 8 \mathrm{~mm}$ stretched mesh size) (Harmelin-Vivien, 1981) during both day and night as diel differences occur in the activity rhythms, feeding behavior and position of fish associated with $P$. oceanica seagrass meadows (Harmelin-Vivien, 1982). Five trawls of 10 min duration at a constant towing speed of $2.8 \mathrm{~km} \mathrm{~h}^{-1}$ (combined surface area covered of $3500 \mathrm{~m}^{2}$ ) were carried out between 8 and $18 \mathrm{~m}$ depth. A total of 588 individuals of $S$. porcus were collected. Once caught, fish were immediately stored on ice in polyethylene bags. In the laboratory, fish were measured to the nearest $\mathrm{mm}$ (total length, TL) before dissection and sex determination. Dissections were performed on an acid $(10 \% \mathrm{HCl})$ cleaned glass worktop with ceramic scalpels and forceps, wearing powder free single use nitrile gloves. All instruments were cleaned with $10 \% \mathrm{HCl}$, rinsed with Milli-Q water between each sample and dried at $100{ }^{\circ} \mathrm{C}$ for $2 \mathrm{~h}$. Dorsal white muscle samples of fish without skin were individually put into polyethylene bags and kept frozen at $-20^{\circ} \mathrm{C}$ until analysis. The number of fish processed per type of analysis is given in Table 1 .

\subsection{Stomach content analysis}

Stomach contents were removed and stored in 95\% ethanol before analysis. As ontogenic variations of diet are high in S. porcus (HarmelinVivien et al., 1989), individuals were separated into three size/age classes (see Section 2.1). Prey items in stomachs were sorted under a stereo microscope to the lowest possible taxonomic group and counted. The different prey categories were grouped according to fish size class, sampling site and period (day or night). Prey items were dried for $24 \mathrm{~h}$ at $50{ }^{\circ} \mathrm{C}$ and weighed $( \pm 0.01 \mathrm{mg}$ dry weight, $\mathrm{dw}$ ). The importance of prey categories in the $S$. porcus diet was assessed by their percentage by number $(\% \mathrm{~N})$, percentage by weight based on digested non-reconstituted prey weight $(\% \mathrm{~W})$, percentage of occurrence $(\% \mathrm{O})$ and index of relative importance (\%IR; Pinkas et al., 1971), calculated as \% $\mathrm{IRI}=(\mathrm{IRI} / \Sigma$ IRI $) \times 100$, where IRI $=\% \mathrm{O} \times(\% \mathrm{~N}+\% \mathrm{~W})$.

\subsection{Otolith analysis}

The age (in years) of the individuals was estimated by the otolith analysis of individuals covering all size/age classes. Sagittal otoliths

\section{Table 1}

Number of individuals of the black scorpionfish Scorpaena porcus by sampling site (CB: Côte Bleue; PB: Prado Bay; PC: Plateau des Chèvres; and HY: Hyères), size/age class (C1: juveniles, $<70 \mathrm{~mm}$ total length (TL), aged $0+$; C2: sub-adults 71-130 $\mathrm{mm}$ TL, $1-3$ years; C3: and adults, > $131 \mathrm{~mm}$ TL, 3-6 years), and sex (U: undetermined; F: female; and M: male) for analyses of stomach contents, isotopic compositions ( $\mathrm{C}$ and $\mathrm{N}$ ) and trace elements (TEs).

\begin{tabular}{|c|c|c|c|c|c|c|c|c|c|c|}
\hline & \multicolumn{4}{|c|}{ Site } & \multicolumn{3}{|c|}{ Class } & \multicolumn{3}{|l|}{ Sex } \\
\hline & $\mathrm{CB}$ & PB & $\mathrm{PC}$ & HY & $\mathrm{C} 1$ & $\mathrm{C} 2$ & $\mathrm{C} 3$ & $\mathrm{U}$ & $\mathrm{F}$ & M \\
\hline Stomach contents & 78 & 110 & 209 & 191 & 45 & 458 & 85 & 128 & 234 & 226 \\
\hline Stable isotopes & 18 & 16 & 13 & 21 & 17 & 34 & 17 & 34 & 18 & 16 \\
\hline Trace elements & 7 & 16 & 19 & 77 & 40 & 72 & 7 & 64 & 30 & 25 \\
\hline
\end{tabular}

were removed, cleaned, weighed $( \pm 0.1 \mathrm{mg})$ and their length $( \pm 0.1 \mathrm{~mm})$ was measured. As weight and length did not differ between right and left otoliths (Wilcoxon tests, $\mathrm{p}>.05$ ), the left otolith was arbitrarily chosen for age reading. Sagittae were immersed in distilled water and observed by transparency using a stereo microscope under reflected light without any additional preparation (Fabien Morat, pers. comm.). Reading was done from the nucleus to the anterior extremity of the rostrum by counting annual annuli. One annulus was the combination of an opaque mark and a hyaline mark, as already observed in other Scorpaenidae (Massutí et al., 2000; La Mesa et al., 2005; Demirhan and Can, 2009; Scarcella et al., 2011). Each otolith was analyzed by three different observers to obtain the fairest estimate of age. Correlation was established between the total otolith length $\left(\mathrm{T}_{\mathrm{o}} \mathrm{L}\right.$, $\mathrm{mm}$ ) and the age of the individuals (years).

\subsection{Isotopic and trace element analyses}

Samples of dorsal white muscle were freeze-dried and ground to a fine powder before analysis (Pinnegar and Polunin, 1999). Measurements of $\mathrm{C}$ and $\mathrm{N}$ isotopic compositions were performed at the individual level with an elemental analyzer (Flash EA 1112, Thermo Scientific, Milan, Italy) coupled with an isotope ratio mass spectrometer (Delta V Advantage with a Conflo IV interface, Thermo Scientific, Bremen, Germany) at the LIENSs stable isotope facility of the University of La Rochelle, France. Briefly, samples of $0.40 \pm 0.01 \mathrm{mg}$ of freezedried powder were weighed and sealed in tin capsules for analysis. The results are expressed following the delta $(\delta)$ notation, as deviations from standards (Vienna Pee Dee Belemnite for $\delta^{13} \mathrm{C}, \mathrm{N}_{2}$ in air for $\delta^{15} \mathrm{~N}$ ): $\delta \mathrm{X}(\% 0)=\left[\left(\mathrm{R}_{\text {sample }} / \mathrm{R}_{\text {standard }}\right)-1\right] \times 10^{3}$, where $\mathrm{X}$ is ${ }^{13} \mathrm{C}$ or ${ }^{15} \mathrm{~N}$ and $\mathrm{R}$ is ${ }^{13} \mathrm{C} /{ }^{12} \mathrm{C}$ or ${ }^{15} \mathrm{~N} /{ }^{14} \mathrm{~N}$, respectively. Analytical precision, based on the analyses of acetanilide (Thermo Scientific), used as laboratory internal standard was $<0.15 \%$ for carbon and nitrogen. Calibration was done using reference materials (USGS-24, IAEA-CH6, -600 for carbon; and IAEA-N2, -NO-3, -600 for nitrogen). The $\mathrm{C} / \mathrm{N}$ ratio provided by the elemental analyzer was used as a proxy of the lipid content. A value of the $\mathrm{C} / \mathrm{N}$ ratio lower than 3.7 indicates that the lipid content is low and does not affect the isotopic composition of carbon (Sweeting et al., 2006). The $\delta^{15} \mathrm{~N}$ value of individuals was used as a proxy of their trophic position, as commonly done (Newsome et al., 2007; Cossa et al., 2012; Sebastiano et al., 2016).

The analysis of $\mathrm{As}, \mathrm{Ba}, \mathrm{Cd}, \mathrm{Cr}, \mathrm{Cu}, \mathrm{T}-\mathrm{Hg}, \mathrm{Ni}, \mathrm{Pb}$ and $\mathrm{Zn}$ in fish was performed at the individual level for the biggest fish and on pools of individuals (from the same site, size/age class and sex) for the smallest ones. The required mineralization of samples was performed on aliquots of $\sim 250 \mathrm{mg}$ digested in $3 \mathrm{~mL}$ (for masses lower than $100 \mathrm{mg}$ ) or $5 \mathrm{~mL}$ (for masses higher than $100 \mathrm{mg}$ ) of a 3:1 (v:v) mixture of $65 \%$ $\mathrm{HNO}_{3}(6 \mathrm{~mL})$ and $37 \% \mathrm{HCl}(2 \mathrm{~mL})$ (Merck Suprapur ${ }^{\circledR}$ quality). Acid mineralization was performed overnight, at room temperature, and then in a microwave for $30 \mathrm{~min}$ with increasing temperature up to $120^{\circ} \mathrm{C}$, and $15 \mathrm{~min}$ at $120^{\circ} \mathrm{C}(1200 \mathrm{~W})$. After the mineralization process, each sample was diluted to $50 \mathrm{~mL}$ with Milli-Q water, according to the volume of acid added to the mineralization. Elements were analyzed using an ICP-OES (Vista-Pro, Varian, Mulgrave, Victoria Australia) or an ICP-MS (X SeriesII, Thermo Fisher Scientific, Bremen, Germany). T-Hg does not require a mineralization step and so it was directly analyzed from the dried samples by atomic absorption spectrometry with an Advanced Mercury Analyzer (AMA 254, Altec, Prague, Czech Republic) as described by Bustamante et al. (2006).

Precision and repeatability of TE analyses were assessed with certified reference materials (dogfish liver DOLT-4 and lobster hepatopancreas TORT-2; NRCC), treated and analyzed in the same way as the samples. The results were in good agreement with the certified values, and the relative standard deviations were always below 15\%, proving good repeatability of the method. Blanks were tested in each analytical batch. All element concentrations were given on a dry weight basis ( $\mu \mathrm{g}$ $\left.\mathrm{g}^{-1} \mathrm{dw}\right)$. The detection limits $\left(\mu \mathrm{g} \mathrm{g}^{-1}\right)$ were $0.0008(\mathrm{~T}-\mathrm{Hg}), 0.003(\mathrm{Cd}$ 
and $\mathrm{Pb}$ ), $0.01(\mathrm{Cr}, \mathrm{Cu}$, and $\mathrm{Ni}$ ), 0.03 (As and $\mathrm{Ba}$ ), and $0.52(\mathrm{Zn})$.

\subsection{Statistical analyses}

Spatial differences in diet composition were tested using Spearman's rank correlations coefficient on the\%IRI of prey categories. Correlations between size and carbon and nitrogen isotopic compositions in fish muscle were assessed using generalized linear models (GLMs; Legendre and Legendre, 2012). GLMs were also used to analyze the correlation between fish size/age classes $\delta^{15} \mathrm{~N}$ values or TE concentrations.

The variability in size, age, isotopic compositions and TE levels were analyzed independently using a univariate PERMANOVA (Anderson, 2001). The PERMANOVA routine was performed for testing the simultaneous responses of one $\left(\delta^{13} \mathrm{C}, \delta^{15} \mathrm{~N}\right.$, and each TE) or more (nine TEs) variables to all factors (site, class and sex) in an analysis of variance (ANOVA and MANOVA) based on an experimental design of any resemblance measure using permutation methods (Anderson, 2001; McArdle and Anderson, 2001; Anderson et al., 2008). The variables were normalized prior to analyses. Euclidean distance similarity matrices were generated. This method is equivalent to a parametric MANOVA, but free from the assumptions of normality and the homoscedasticity of residuals (Anderson, 2001). $P$-values were obtained using 9999 random unrestricted permutations of raw data and Type I sums of squares. Monte Carlo $P$-values were considered when there were not enough possible permutations $(<2000)$. Significance was set at $P$-value less than $0.05\left({ }^{*}=0.05,{ }^{* *}=0.01\right.$, and $\left.{ }^{* * *}=0.001\right)$. The differences in mean TE concentrations between site, class and sex were described by a non-metric Multi-Dimensional Scaling ordination (nMDS; Clarke 1993; Clarke and Gorley 2006) calculated by the dissimilarity matrix among samples on the basis of the binomial dissimilarity measure (Anderson, 2001). If the stress levels from 2-dimensional ordination plots were lower than 0.2 , the analyses were validated (Clarke 1993). Then, correlation vectors were calculated with the Spearman rank correlation index. Lastly, a multivariate PERMANOVA (Anderson, 2001) was performed, based on the binomial deviance (scaled) dissimilarity measures. Analyses were performed using PRIMER 6 software (6.1.16) and the PERMANOVA add-on (1.06) (Plymouth Marine Laboratory, Plymouth, United Kingdom) (Clarke and Warwick, 2001).

\section{Results}

\subsection{Size, age and sex ratio}

A total of 588 individuals were sampled (78 at CB, 110 at PB, 209 at PC, and 191 at HY). Fish were classified into three classes corresponding to three age and size classes: (C1) juveniles (aged $0+,<70 \mathrm{~mm} \mathrm{TL}$ ); (C2) sub-adults (1-3 years, 71-130 mm TL); and (C3) adults (3-6 years, $>131 \mathrm{~mm}$ TL) (Table 2). The average total length for all individuals was $109 \mathrm{~mm}( \pm 29 \mathrm{~mm}$ ) for a mean age of 2 years ( \pm 1 year). A significant difference among sampling sites was observed, with larger and older individuals at HY than at the three Marseille (i.e., PB, CB, PC) sites (PERMANOVA, $\mathrm{F}=14.19, \mathrm{p}<.001$, $\mathrm{HY}>\mathrm{PB}=\mathrm{CB}=\mathrm{PC}$, for TL; and PERMANOVA, $\mathrm{F}=17.25, \mathrm{p}<.001$, $\mathrm{HY}>\mathrm{PB}=\mathrm{PC}=\mathrm{CB}$, for age). The sex ratio was well balanced $(51 \%$ females; $49 \%$ males) and independent of sampling site (PERMANOVA, $\mathrm{F}=1.28, \mathrm{p}>.05$ ). Fish with indeterminate sex represented $20 \%$ of samples, with the predominance of juvenile individuals in the smallest size/age class.

\subsection{Diet}

Out of the 588 individuals analyzed, 103 had empty stomachs (27\%) and 18 contained prey items at an advanced state of decomposition (3\%) that did not allow correct taxonomic identification. The results were therefore obtained from the analysis of 467 stomach
Table 2

Mean ( \pm SD) size and age of Scorpaena porcus according to sampling site and size/age class.

\begin{tabular}{llll}
\hline Site & Class & Total length (mm) & Age (year) \\
\hline Côte Bleue (CB) & Juveniles & $54 \pm 12$ & $0^{+}$ \\
& Sub-adults & $105 \pm 19$ & $1.58 \pm 0.79$ \\
& Adults & $160 \pm 27$ & $3.67 \pm 1.15$ \\
Prado Bay (PB) & Juveniles & $41 \pm 5$ & $0^{+}$ \\
& Sub-adults & $86 \pm 20$ & $1.14 \pm 0.69$ \\
& Adults & $161 \pm 8$ & $3.75 \pm 0.50$ \\
Plateau des Chèvres (PC) & Juveniles & $51 \pm 10$ & $0^{+}$ \\
& Sub-adults & $100 \pm 14$ & $1.40 \pm 0.55$ \\
& Adults & $159 \pm 21$ & $4.00 \pm 0.82$ \\
& Juveniles & $67 \pm 2$ & $0.20 \pm 0.45$ \\
Hyères (HY) & Sub-adults & $101 \pm 10$ & $1.50 \pm 0.53$ \\
& Adults & $152 \pm 25$ & $3.67 \pm 1.03$ \\
\hline
\end{tabular}

contents. Diet composition differed significantly between size/age classes (Spearman $\mathrm{rS}$, all $\mathrm{p}<.05$ ), indicating a gradual change in $S$. porcus diet with the growth of individuals and an increase in mean prey size (Table 3). Juveniles preyed mainly on small crustaceans, such as small Caridea, isopods and amphipods, while subadults and adults consumed more diversified and larger prey, such as Brachyura and Teleostei. However, Caridea remained the principal prey in all size/age classes. Subadults consumed less Isopoda and Amphipoda and more Brachyoura, Galatheidae and Teleostei than juveniles. The diet of adults mainly consisted of Caridea, Teleostei and Brachyura. If the prey categories consumed by $S$. porcus were the same at all sampling sites, with Caridea always preferentially consumed, their relative proportions in the fish diet differed significantly among sites, with individuals from $\mathrm{PB}$ and PC differing from those of CB and HY. S. porcus from PB and PC presented similar diets $(\mathrm{rS}=0.79, \mathrm{p}>.05)$, with higher proportions of Caridea (65.0 and 81.7\%IRI, respectively) and Amphipoda (14.0 and 10.0\% IRI, respectively) consumed, than at CB and HY (Caridea: 33.2 and 57.4\%IRI, respectively; and Amphipoda: $<3 \%$ IRI). In contrast, the diet of $S$. porcus was similar at $\mathrm{CB}$ and $\mathrm{HY}(\mathrm{rS}=0.71, \mathrm{p}>.05)$, where the species ingested higher proportions of Isopoda (15.5\% and $25.9 \%$ IRI, respectively), Galathea ( $>3.0 \%$ IRI) and Teleostei (8.7 and 3.0\% IRI, respectively), than at $\mathrm{PB}$ and PC (Isopoda: $<2.0 \%$ IRI; Galathea: $<1.0 \%$ IRI; and Teleostei: $<2.0 \%$ IRI).

\subsection{Stable isotope compositions}

In this study, the mean $\mathrm{C} / \mathrm{N}$ ratio of $S$. porcus muscle was $3.2 \pm 0.1$ (Table 4), so no correction was applied on $\delta^{13} \mathrm{C}$ values for lipids. A wide range of $\delta^{13} \mathrm{C}$ values was observed among all $S$. porcus analyzed (from -18.8 to $-16.5 \%, \Delta \delta^{13} \mathrm{C}=2.3 \%$ ) and $\delta^{15} \mathrm{~N}$ values (from 6.4 to $12.0 \%, \Delta \delta^{15} \mathrm{~N}=5.6 \%$ ). Such variations were related to differences among both sites and size/age classes (Fig. 2). Carbon isotopic compositions were significantly less enriched for individuals collected at PC and $\mathrm{PB}$ than at $\mathrm{CB}$ and $\mathrm{HY}$ (PERMANOVA, $\mathrm{F}=37.43$, for $\delta^{13} \mathrm{C}$; $\mathrm{p}<.001$ ), and $\delta^{15} \mathrm{~N}$ values were significantly lower at $\mathrm{HY}$ than at $\mathrm{CB}$, $\mathrm{PB}$ and PC (PERMANOVA, $\mathrm{F}=57.74$, for $\delta^{15} \mathrm{~N}, \mathrm{p}<.001$ ) (Table 4). In addition, juveniles exhibited significantly lower $\delta^{13} \mathrm{C}$ and $\delta^{15} \mathrm{~N}$ values than adults, regardless of the site (PERMANOVA, $\mathrm{F}=4.79, \mathrm{p}<.01$, for $\delta^{13} \mathrm{C} ; \mathrm{F}=21.06, \mathrm{p}<.001$ for $\left.\delta^{15} \mathrm{~N}\right)$. Significant correlations between length and $\delta^{15} \mathrm{~N}$ values were observed at $\mathrm{CB}\left(\mathrm{R}^{2}=0.55\right.$, $\mathrm{p}<.001), \mathrm{PB}\left(\mathrm{R}^{2}=0.34, \mathrm{p}<.05\right), \mathrm{PC}\left(\mathrm{R}^{2}=0.64, \mathrm{p}<.01\right)$ and $\mathrm{HY}$ $\left(\mathrm{R}^{2}=0.69, \mathrm{p}<.001\right)$, while all correlations between $\mathrm{TL}$ and $\delta^{13} \mathrm{C}$ values were not significant ( $\mathrm{p}>.05$ at all sampling sites) (Fig. 3).

\subsection{TE concentrations}

All TEs analyzed were found in varying concentrations (Table 5). Ranges of detected concentrations for the nine elements quantified in $S$. 
Table 3

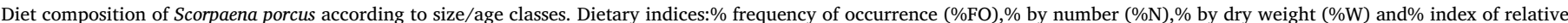

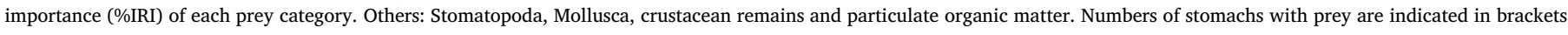

\begin{tabular}{|c|c|c|c|c|c|c|c|c|c|c|c|c|}
\hline \multirow[t]{2}{*}{ Prey items } & \multicolumn{4}{|c|}{ Juveniles (43) } & \multicolumn{4}{|c|}{ Sub-adults (363) } & \multicolumn{4}{|c|}{ Adults (79) } \\
\hline & $\% \mathrm{FO}$ & $\% \mathrm{~N}$ & $\% \mathrm{~W}$ & \%IRI & $\% \mathrm{FO}$ & $\% \mathrm{~N}$ & $\% \mathrm{~W}$ & \%IRI & $\% \mathrm{FO}$ & $\% \mathrm{~N}$ & $\% \mathrm{~W}$ & \%IRI \\
\hline \multicolumn{13}{|l|}{ Crustacea } \\
\hline Amphipoda & 25.0 & 22.2 & 5.1 & 15.6 & 9.5 & 7.5 & 1.4 & 3.6 & 0.6 & 0.5 & $<0.1$ & $<0.1$ \\
\hline Isopoda & 26.3 & 22.8 & 25.4 & 24.5 & 12.9 & 10.3 & 4.9 & 7.3 & 7.6 & 7.8 & 2.8 & 4.2 \\
\hline Caridea & 40.8 & 48.7 & 65.1 & 57.6 & 35.4 & 46.8 & 42.2 & 56.6 & 31.3 & 38.4 & 26.4 & 40.9 \\
\hline Brachyura & - & - & - & - & 8.8 & 8.2 & 19.3 & 9.4 & 19.8 & 16.5 & 31.7 & 17.8 \\
\hline Galathea & 1.2 & 0.7 & 2.5 & 0.5 & 8.1 & 6.0 & 13.0 & 7.4 & 7.9 & 7.2 & 3.6 & 4.0 \\
\hline Annelida & 1.6 & 1.6 & 0.8 & 0.5 & 1.9 & 2.3 & 0.5 & 0.3 & 0.6 & 0.5 & $<0.1$ & $<0.1$ \\
\hline Teleostei & - & - & - & - & 4.2 & 2.8 & 11.0 & 4.8 & 10.8 & 10.3 & 29.5 & 19.2 \\
\hline Others & 5.0 & 4.0 & 1.0 & 1.4 & 19.3 & 16.0 & 7.8 & 10.7 & 21.9 & 19.0 & 6.0 & 13.7 \\
\hline
\end{tabular}

porcus muscles were as follows: (min-max values): $11.15-144.50 \mu \mathrm{g}$ As $\mathrm{g}^{-1} \mathrm{dw} ; 0.18-0.37 \mu \mathrm{g} \quad \mathrm{Ba} \mathrm{g}^{-1} \mathrm{dw} ; 0.02-0.04 \mu \mathrm{g} \quad \mathrm{Cd}^{-1} \mathrm{dw}$;

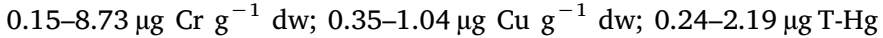
$\mathrm{g}^{-1} \mathrm{dw} ; 0.10-4.69 \mu \mathrm{g} \mathrm{Ni} \mathrm{g}{ }^{-1} \mathrm{dw} ; 0.02-0.07 \mu \mathrm{g} \mathrm{Pb} \mathrm{g} \mathrm{g}^{-1} \mathrm{dw}$; and

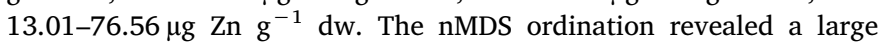
variation of element concentrations in the muscle of $S$. porcus among sampling sites and size classes of individuals (PERMANOVA, $\mathrm{F}=12.50$, $\mathrm{p}<.05$, for site; $\mathrm{F}=19.37, \mathrm{p}<.05$, for class) (Fig. 4a and $\mathrm{b}$ ).

$\mathrm{As}, \mathrm{Ba}, \mathrm{Cd}, \mathrm{T}-\mathrm{Hg}, \mathrm{Pb}$, and $\mathrm{Zn}$ concentrations displayed significant differences among the four sampling sites (Table 5, Fig. 5). Pair-wise tests showed that the highest TE concentrations were not always measured in the same site. As concentration was significantly higher at PC than at the three other sites. Higher Ba concentrations were found at $\mathrm{CB}$ and $\mathrm{PB}$ than $\mathrm{PC}$ and $\mathrm{HY}$, while the highest $\mathrm{T}-\mathrm{Hg}$ concentrations were recorded in the Bay of Marseille at PB and PC. Concentrations of $\mathrm{Cd}, \mathrm{Pb}$ and $\mathrm{Zn}$ were all higher at the three Marseille sites than at $\mathrm{HY}$. $\mathrm{Cr}, \mathrm{Cu}$ and $\mathrm{Ni}$ were the only elements that did not statistically differ in concentration with site. TE concentrations also displayed significant differences among fish size classes, except for $\mathrm{Cr}$, Ni and $\mathrm{Zn}$ (PERMANOVA, $\mathrm{F}=16.73, \mathrm{p}<.05$ for As; $\mathrm{F}=103.82, \mathrm{p}<.01$ for Ba; $\mathrm{F}=5.85, \mathrm{p}<.01$ for $\mathrm{Cd} ; \mathrm{F}=26.62, \mathrm{p}<.05$ for $\mathrm{Cu} ; \mathrm{F}=2115.00$, $\mathrm{p}<.01$ for T-Hg; and $\mathrm{F}=1408.40, \mathrm{p}<.01$ for $\mathrm{Pb}$ ), while sex had no effect on TE concentrations (results not shown, PERMANOVA, $\mathrm{F}=5.46, \mathrm{p}>\mathrm{.05}$ ). Pair-wise tests revealed that adults always presented the highest concentrations in As and T-Hg (Fig. 4). In contrast, $\mathrm{Ba}, \mathrm{Cd}, \mathrm{Cu}$ and $\mathrm{Pb}$ concentrations were significantly higher in either juveniles or in sub-adults. The potential trophic transfer of TEs was estimated using the relationships between trace element concentrations and $\delta^{15} \mathrm{~N}$ values of individuals. Generally, a significant positive correlation between them indicates that the element is biomagnified through the food chain, whereas a significant negative correlation suggests that

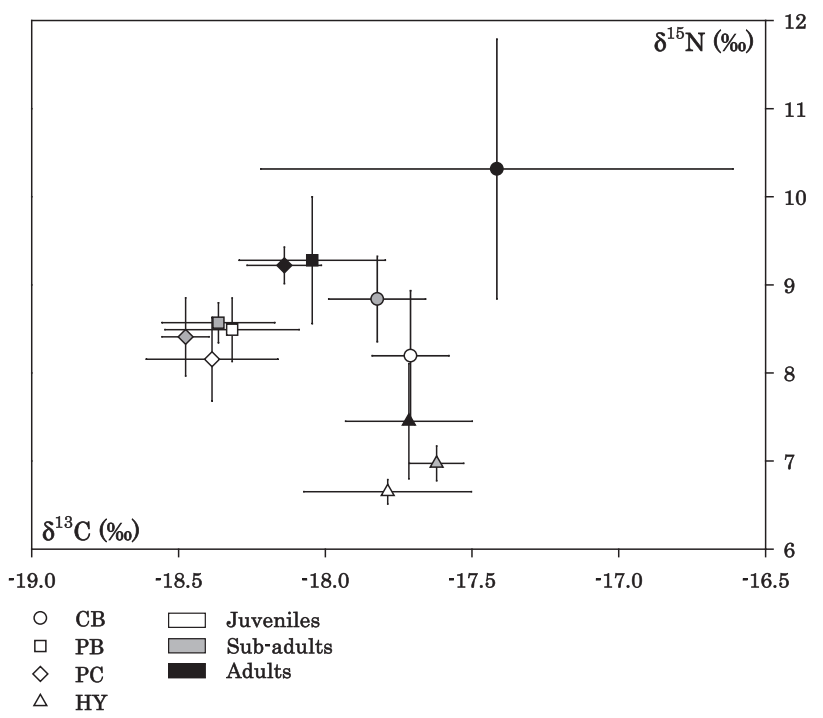

Fig. 2. $\mathrm{C}$ and $\mathrm{N}$ isotopic compositions (\%) in the muscle of Scorpaena porcus according to sampling site (O CB: Côte Bleue; $\square$ PB: Prado Bay; $\diamond$ PC: Plateau des Chèvres; and $\Delta$ HY: Hyères) and size/age classes of individuals (white: juveniles $<70 \mathrm{~mm}$ total length, aged $0+$; gray: sub-adults 71-130 mm, 1-3 years; and black: adults > $131 \mathrm{~mm}, 3-6$ years).

biodiminution has occurred. In the present study, for all individuals combined, significant correlations between age, size and $\delta^{15} \mathrm{~N}$ values were observed for $\mathrm{T}-\mathrm{Hg}(\mathrm{r}=0.88, \mathrm{p}<.001, \mathrm{r}=0.84, \mathrm{p}<.001$, and $\mathrm{r}=0.68, \mathrm{p}<.01$, respectively), but not for the eight other TEs analyzed. Positive, but not significant, correlations $(p>.05$ ) were observed for As and negative, but not significant, correlations $(\mathrm{p}>.05)$ for the other TEs.

Table 4

$\mathrm{C}$ and $\mathrm{N}$ isotopic compositions and $\mathrm{C} / \mathrm{N}($ Mean $\pm \mathrm{SD}$ ) of Scorpaena porcus muscles according to sampling site and class.

\begin{tabular}{|c|c|c|c|c|c|c|}
\hline Site & Class & Total length (mm) & Age (year) & $\delta^{13} \mathrm{C}(\% 0)$ & $\delta^{15} \mathrm{~N}(\% 0)$ & $\mathrm{C} / \mathrm{N}$ \\
\hline \multirow[t]{3}{*}{ Côte Bleue (CB) } & Juveniles & $54 \pm 12$ & $0^{+}$ & $-17.7 \pm 0.1$ & $8.2 \pm 0.7$ & $3.2 \pm<0.1$ \\
\hline & Sub-adults & $105 \pm 19$ & $1.58 \pm 0.79$ & $-17.8 \pm 0.2$ & $8.8 \pm 0.5$ & $3.2 \pm<0.1$ \\
\hline & Adults & $160 \pm 27$ & $3.67 \pm 1.15$ & $-17.4 \pm 0.8$ & $10.3 \pm 1.5$ & $3.2 \pm<0.1$ \\
\hline \multirow[t]{3}{*}{ Prado Bay (PB) } & Juveniles & $41 \pm 5$ & $0^{+}$ & $-18.3 \pm 0.2$ & $8.5 \pm 0.4$ & $3.2 \pm<0.1$ \\
\hline & Sub-adults & $86 \pm 20$ & $1.14 \pm 0.69$ & $-18.4 \pm 0.2$ & $8.6 \pm 0.2$ & $3.2 \pm<0.1$ \\
\hline & Adults & $161 \pm 8$ & $3.75 \pm 0.50$ & $-18.0 \pm 0.3$ & $9.3 \pm 0.7$ & $3.1 \pm<0.1$ \\
\hline \multirow[t]{3}{*}{ Plateau des Chèvres (PC) } & Juveniles & $51 \pm 10$ & $0^{+}$ & $-18.4 \pm 0.2$ & $8.2 \pm 2.9$ & $3.2 \pm<0.1$ \\
\hline & Sub-adults & $100 \pm 14$ & $1.40 \pm 0.55$ & $-18.5 \pm 0.1$ & $8.4 \pm 0.4$ & $3.2 \pm<0.1$ \\
\hline & Adults & $159 \pm 21$ & $4.00 \pm 0.82$ & $-18.1 \pm 0.1$ & $9.2 \pm 0.2$ & $3.2 \pm 0.1$ \\
\hline \multirow[t]{3}{*}{ Hyères (HY) } & Juveniles & $67 \pm 2$ & $0.20 \pm 0.45$ & $-17.8 \pm 0.3$ & $6.7 \pm 0.1$ & $3.2 \pm<0.1$ \\
\hline & Sub-adults & $101 \pm 10$ & $1.50 \pm 0.53$ & $-17.6 \pm 0.1$ & $7.0 \pm 0.2$ & $3.2 \pm<0.1$ \\
\hline & Adults & $152 \pm 25$ & $3.67 \pm 1.03$ & $-17.7 \pm 0.2$ & $7.5 \pm 0.7$ & $3.2 \pm 0.1$ \\
\hline
\end{tabular}




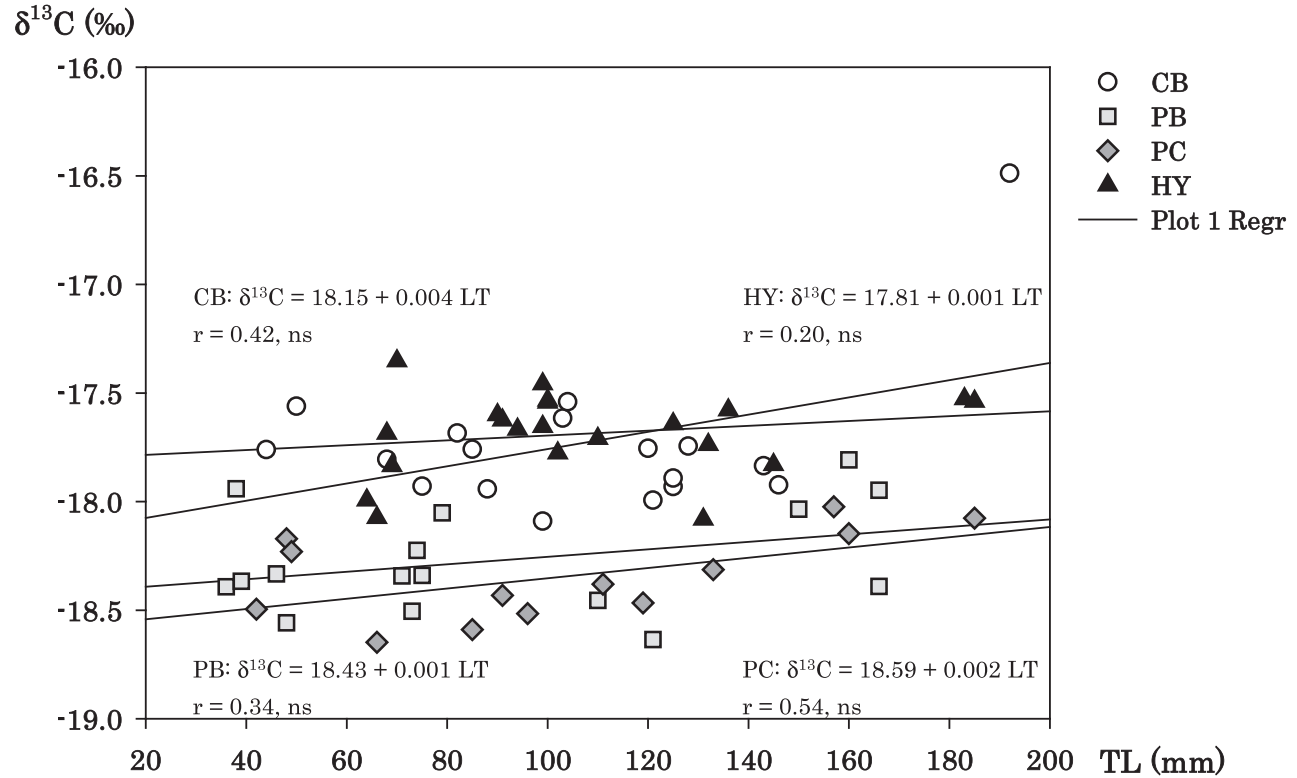

Fig. 3. Linear correlation between total length (TL, $\mathrm{mm}$ ), and $\mathrm{C}$ and $\mathrm{N}$ isotopic compositions (\%o) of Scorpaena porcus at the four sampling sites (white circle: $\mathrm{CB}$; light gray square: $\mathrm{PB}$; gray diamond: PC; and black triangle: HY). ${ }^{* * * *}$ : $p<.001 ;{ }^{* *}: p<.01 ;{ }^{*}: p<.05$; and ns (nonsignificant): $\mathrm{p}>.05$.

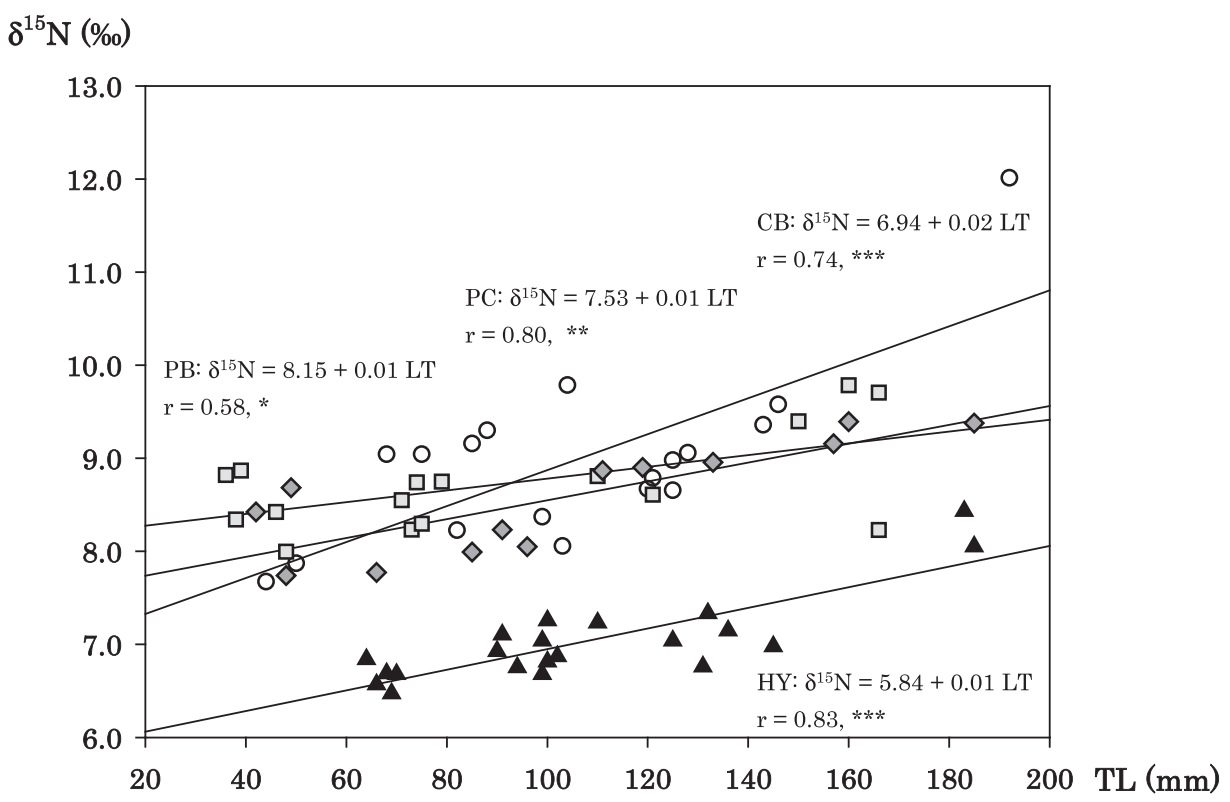

\section{Discussion}

This study provided baseline information on the concentration status of nine TEs in the black scorpionfish Scorpaena porcus, a common sedentary fish representative of the spatial variation of coastal environments in the northwestern Mediterranean Sea. Three elements $(\mathrm{Cd}, \mathrm{Hg}$ and $\mathrm{Pb})$ have been more studied as they are subjected to international regulation (EC, 2006), while the others, (As, $\mathrm{Cr}, \mathrm{Cu}, \mathrm{Ba}, \mathrm{Ni}$, and $\mathrm{Zn}$ ) have rarely been previously investigated in this region.

\subsection{Influence of site}

Contamination patterns are driven by local contamination sources, environmental factors and the biology of the species (Cossa et al., 2012; Cresson et al., 2015a), and assessing a site-specific contamination pattern requires a good understanding of all these parameters. The quantification of TE concentrations in the muscle of $S$. porcus collected in seagrass beds, combined with the measurement of $\mathrm{C}$ and $\mathrm{N}$ isotopic compositions, allowed the discrimination of local populations from four coastal sites investigated in the northwestern Mediterranean Sea. It was also demonstrated that spatial patterns of TE concentrations differed among trace elements, but As and Zn were always the most concentrated TEs, and $\mathrm{Ba}, \mathrm{Pb}$, and $\mathrm{Cd}$ the least concentrated ones. $\mathrm{Cr}, \mathrm{Cu}$, and Ni were the only three TEs that displayed similar concentrations in $S$. porcus muscle at all sites. This could likely be related to the similar concentrations of these elements in the main crustacean prey species ingested by $S$. porcus at these sites (Ourgaud, unpublished data), as food is the main route of TE inputs in fish (Hall et al., 1997). On the reverse, the other TEs analyzed exhibited significant spatial variations. The highest As concentration was observed at PC, while higher T-Hg levels were recorded at $\mathrm{PB}$ and $\mathrm{PC}$, and higher Ba levels at $\mathrm{CB}$ and $\mathrm{PC}$. $\mathrm{Cd}, \mathrm{Pb}$ and $\mathrm{Zn}$ were all observed in higher concentrations at the three sites of the Bay of Marseille compared to the site located at HY. These results reflected a higher anthropic influence in Marseille Bay than at Hyères, due to the size and scale of the activity of this large city, as TEs are commonly used in many industrial, harbor and urban activities (The MERMEX Group, 2011; Bonnard et al., 2012; Oursel et al, 2013; Falcy et al., 2014). Moreover, the Bay of Marseille is subjected also to additional TE inputs related to the sporadic intrusions of Rhône River waters in the north of the bay (Sempéré et al., 2000; Fraysse et al., 2014). 
Table 5

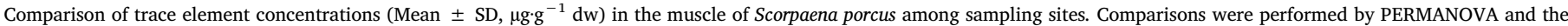
Pair-wise column refers to the sites compared. ${ }^{* * *}: p<.001 ;{ }^{* *}: p<.01 ;{ }^{*}: p<.05$; and ns (non-significant): $p>.05$.

\begin{tabular}{|c|c|c|c|c|c|c|c|}
\hline & Côte Bleue (CB) & Prado Bay (PB) & Plateau des Chèvres (PC) & Hyères (HY) & PERMANOVA & $p$ & Pair-wise test (site) \\
\hline As & $\begin{array}{l}25.63 \pm 14.19 \\
(17.44-42.01)\end{array}$ & $\begin{array}{l}31.27 \pm 23.77 \\
(11.15-57.50)\end{array}$ & $\begin{array}{l}89.53 \pm 48.16 \\
(54.72-144.5)\end{array}$ & $\begin{array}{l}45.59 \pm 11.72 \\
(26.37-66.30)\end{array}$ & $F=15.99$ & * & $\mathrm{PC}>\mathrm{HY}-\mathrm{PB}-\mathrm{CB}$ \\
\hline $\mathrm{Ba}$ & $\begin{array}{l}\mathbf{0 . 3 0} \pm \mathbf{0 . 0 9} \\
(0.19-0.35)\end{array}$ & $\begin{array}{l}\mathbf{0 . 2 6} \pm \mathbf{0 . 1 0} \\
(0.19-0.37)\end{array}$ & $\begin{array}{l}\mathbf{0 . 2 3} \pm \mathbf{0 . 0 6} \\
(0.18-0.30)\end{array}$ & $\begin{array}{l}\mathbf{0 . 2 2} \pm \mathbf{0 . 0 1} \\
(0.20-0.23)\end{array}$ & $\mathrm{F}=84.23$ & *** & $\mathrm{CB}-\mathrm{PB}>\mathrm{PC}-\mathrm{HY}$ \\
\hline $\mathrm{Cd}$ & $\begin{array}{l}\mathbf{0 . 0 2 9} \pm \mathbf{0 . 0 1 0} \\
(0.02-0.04)\end{array}$ & $\begin{array}{l}\mathbf{0 . 0 2 5} \pm \mathbf{0 . 0 1 2} \\
(0.02-0.04)\end{array}$ & $\begin{array}{l}\mathbf{0 . 0 2 1} \pm \mathbf{0 . 0 1 4} \\
(0.02-0.03)\end{array}$ & $\begin{array}{l}<0.020 \\
-\end{array}$ & $\mathrm{F}=4.97$ & *** & $\mathrm{CB}-\mathrm{PB}-\mathrm{PC}>\mathrm{HY}$ \\
\hline $\mathrm{Cr}$ & $\begin{array}{l}\mathbf{0 . 6 4} \pm \mathbf{0 . 2 8} \\
(0.48-0.96)\end{array}$ & $\begin{array}{l}2.72 \pm 4.16 \\
(0.18-7.53)\end{array}$ & $\begin{array}{l}\mathbf{1 . 7 5} \pm \mathbf{0 . 9 4} \\
(0.83-2.70)\end{array}$ & $\begin{array}{l}2.78 \pm 3.32 \\
(0.15-8.73)\end{array}$ & $\mathrm{F}=0.93$ & $\mathrm{~ns}$ & \\
\hline $\mathrm{Cu}$ & $\begin{array}{l}\mathbf{0 . 5 8} \pm \mathbf{0 . 0 1} \\
(0.57-0.58)\end{array}$ & $\begin{array}{l}\mathbf{0 . 5 0} \pm \mathbf{0 . 1 5} \\
(0.35-0.65)\end{array}$ & $\begin{array}{l}\mathbf{0 . 6 0} \pm \mathbf{0 . 1 0} \\
(0.49-0.68)\end{array}$ & $\begin{array}{l}\mathbf{0 . 5 6} \pm \mathbf{0 . 1 6} \\
(0.38-1.04)\end{array}$ & $\mathrm{F}=3.44$ & $\mathrm{~ns}$ & \\
\hline $\mathrm{Hg}$ & $\begin{array}{l}\mathbf{0 . 7 0} \pm \mathbf{0 . 4 7} \\
(0.42-1.24)\end{array}$ & $\begin{array}{l}1.03 \pm 1.01 \\
(0.44-2.19)\end{array}$ & $\begin{array}{l}\mathbf{0 . 9 3} \pm \mathbf{0 . 8 6} \\
(0.30-1.91)\end{array}$ & $\begin{array}{l}\mathbf{0 . 4 8} \pm \mathbf{0 . 2 7} \\
(0.24-1.35)\end{array}$ & $F=196.07$ & $* *$ & $\mathrm{~PB}-\mathrm{PC}>\mathrm{CB}-\mathrm{HY}$ \\
\hline $\mathrm{Ni}$ & $\begin{array}{l}\mathbf{0 . 3 3} \pm \mathbf{0 . 0 5} \\
(0.28-0.36)\end{array}$ & $\begin{array}{l}\mathbf{0 . 3 6} \pm \mathbf{0 . 3 9} \\
(0.10-0.81)\end{array}$ & $\begin{array}{l}\mathbf{0 . 5 2} \pm \mathbf{0 . 3 2} \\
(0.23-0.87)\end{array}$ & $\begin{array}{l}1.33 \pm 1.87 \\
(0.10-4.69)\end{array}$ & $\mathrm{F}=0.38$ & ns & \\
\hline $\mathrm{Pb}$ & $\begin{array}{l}\mathbf{0 . 0 2 9} \pm \mathbf{0 . 0 1 0} \\
(0.02-0.04)\end{array}$ & $\begin{array}{l}\mathbf{0 . 0 2 5} \pm \mathbf{0 . 0 1 2} \\
(0.02-0.04)\end{array}$ & $\begin{array}{l}\mathbf{0 . 0 2 8} \pm \mathbf{0 . 0 1 9} \\
(0.02-0.07)\end{array}$ & $\begin{array}{l}\mathbf{0 . 0 2 3} \pm \mathbf{0 . 0 0 5} \\
(0.02-0.03)\end{array}$ & $F=1090.70$ & $* *$ & $\mathrm{PC}-\mathrm{CB}-\mathrm{PB}>\mathrm{HY}$ \\
\hline $\mathrm{Zn}$ & $\begin{array}{l}48.66 \pm 5.45 \\
(45.52-54.95)\end{array}$ & $\begin{array}{l}61.62 \pm 12.95 \\
(53.96-76.56)\end{array}$ & $\begin{array}{l}46.89 \pm 15.85 \\
(29.48-60.50)\end{array}$ & $\begin{array}{l}15.57 \pm 1.92 \\
(13.01-19.07)\end{array}$ & $F=619.20$ & $* * * *$ & $\mathrm{~PB}-\mathrm{CB}-\mathrm{PC}>\mathrm{HY}$ \\
\hline
\end{tabular}

High concentrations of As and $\mathrm{Zn}$ are often recorded in marine fish and shellfish (Kim et al., 2007a; Copat et al. 2013; Vieira et al., 2015). The high As concentrations observed in S. porcus at PC could be related to As inputs in the marine environment by Cortiou sewage waters (Oursel et al., 2013) but also by high industrial effluents dumped into the Cassidaigne canyon located eastward, not far from PC and upstream from the main current (Millot, 1999). The higher concentrations of $\mathrm{Zn}$ compared to those of other essential elements, partly resulted from its crucial importance for living organisms, which is well studied in fish (Watanabe et al., 1997; Bury et al., 2003; Pouil et al., 2017). However, the high concentrations of $\mathrm{Zn}$ recorded in S. porcus in Marseille sites could also be attributed to its high level in the local environment. $\mathrm{Zn}$ is considered as an anthropogenic component, used, for example, in $\mathrm{Zn}$ based sacrificial anodes of boat traffic and in other industrial activities (Matthiessen et al., 1999; Hu et al., 2013). As with most contaminants, As and $\mathrm{Zn}$ are predominantly assimilated and bioaccumulated from dietary sources and surrounding waters (Xu and Wang 2002; Bury et al., 2003; Mathews and Fisher 2009).

Spatial variations of TE concentrations in $S$. porcus could be related, in part, to differences in their isotopic compositions, themselves linked to differences in the isotopic values of organic matter (OM) sources among sites. First, the lower $\delta^{13} \mathrm{C}$ values found in $S$. porcus individuals at PC and PB in Marseille Bay could be explained by a higher influence of riverine $\mathrm{OM}$ inputs at these sites, as continental OM is known to be depleted in ${ }^{13} \mathrm{C}$ compared to marine OM (Riera and Richard, 1997; Kim et al., 2007a, 2007b; Harmelin-Vivien et al. 2008). Second, the higher $\delta^{15} \mathrm{~N}$ values of fish from the three Marseille sites reflected an organic enrichment of the environment due to higher anthropogenic inputs in this area (Darnaude et al., 2004; Cresson et al., 2012). The similar lower $\delta^{13} \mathrm{C}$ values of $S$. porcus at PC and PB could be related to local inputs of freshwater from the Cortiou sewage treatment plant and the Huveaune River, as already measured in coastal OM and phytoplankton at these sites by Rastorgueff et al. (2011) and Cresson et al. (2012). Fish from PC were exposed daily to the sewage waters of Cortiou, composed of the treated effluent from the Marseille conurbation and the waters of the Huveaune, Prado, and Jarret rivers. During heavy rains, the Huveaune River waters were directly discharged into Prado Bay and had an impact on fish from PB seagrass meadows (Oursel et al., 2013). At these sites, $S$. porcus presented particularly high concentrations of $\mathrm{As}, \mathrm{Pb}, \mathrm{T}$ $\mathrm{Hg}$ and $\mathrm{Zn}$, all TEs mainly related to anthropic activities but also $\mathrm{Ba}$, which traces from a continental influence. In the area, the Rhône River is the most important source of Ba (Salminen et al., 2005), which may explain the highest Ba concentration in $S$. porcus recorded at $\mathrm{CB}$, a site more subjected to the sporadic influence of this river than PB and PC (Fraysse et al., 2014). Thus, differences in the proportions of terrestrial and marine organic matter inputs at the base of seagrass food webs between Marseille Bay and Hyères were reflected in the differences of isotopic compositions observed in S. porcus from the two areas (i.e., lower $\delta^{13} \mathrm{C}$ values and higher $\delta^{15} \mathrm{~N}$ values at Marseille, higher $\delta^{13} \mathrm{C}$ values and lower $\delta^{15} \mathrm{~N}$ values at Hyères), and in their concentrations of some trace elements (generally higher $\mathrm{As}, \mathrm{Ba}, \mathrm{Cd}, \mathrm{T}-\mathrm{Hg}, \mathrm{Pb}$, and $\mathrm{Zn}$ at Marseille linked to higher human and industrial pressures).

\subsection{Influence of diet and trophic level}

The dietary uptake is the dominant entry pathway of contaminants in most organisms (Zhao et al., 2001) and the main route for TE bioaccumulation (Willis and Sunda, 1984; Hall et al., 1997; Xu and Wang 2002). Contaminant concentration in organisms depends on many factors: trophic group, biological characteristics (e.g., species, swimming behavior, metabolic activities), uptake and elimination kinetics, chemical speciation and bioavailability of contaminants, local environmental conditions (salinity, temperature, $\mathrm{pH}$, alkalinity, etc.), and concentrations in water and sediments (Canli and Atli, 2003). Bioavailability of TEs from ingested food is strongly influenced by the nature of the food and varies considerably among species (e.g., Luoma et al., 2002). As $S$. porcus is a sedentary species (Bell and HarmelinVivien, 1983), isotopic compositions and TE concentrations measured in its muscles reflect its local feeding in Posidonia oceanica seagrass meadows. Its diet is mainly composed of Decapoda crustaceans and Teleostei. Spatial variability in fish diet could also be linked to spatial differences (nature and frequency) of organic matter inputs, and contributed to explain spatial differences in TE concentrations. The high similarity of fish diet at $\mathrm{PC}$ and $\mathrm{PB}$ could be related to the chronic inputs of terrestrial and sewage water POM (Oursel et al., 2013), which favored the populations of detritivorous benthic invertebrates (Amphipoda, Caridea, Brachyoura, Anomura) (Bellan et al., 1980), found in large numbers in the stomach contents of $S$. porcus at these sites. The higher consumption of these detritivorous prey at PC and PB contributed in turn to a higher concentrations in some trace elements, such as $\mathrm{Hg}$, in fish from these sites.

A significant increase of $\delta^{15} \mathrm{~N}$ values with size and age was observed 
(A)

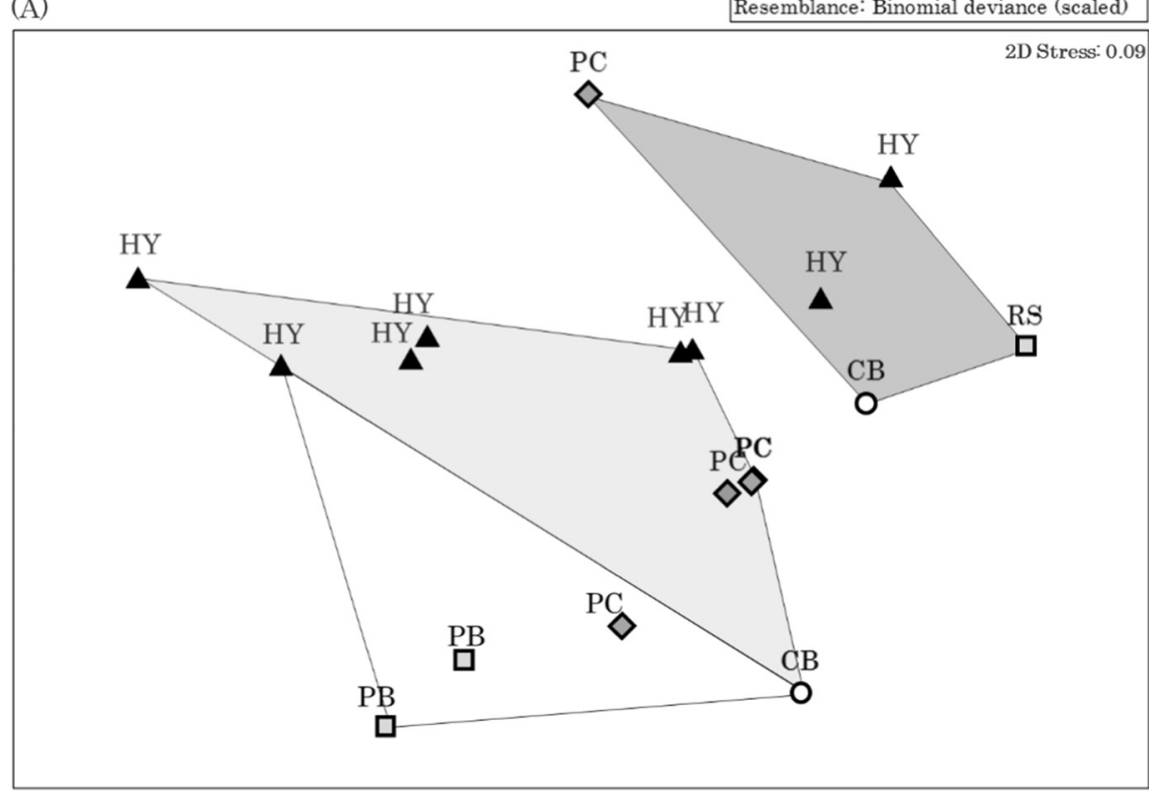

(B)

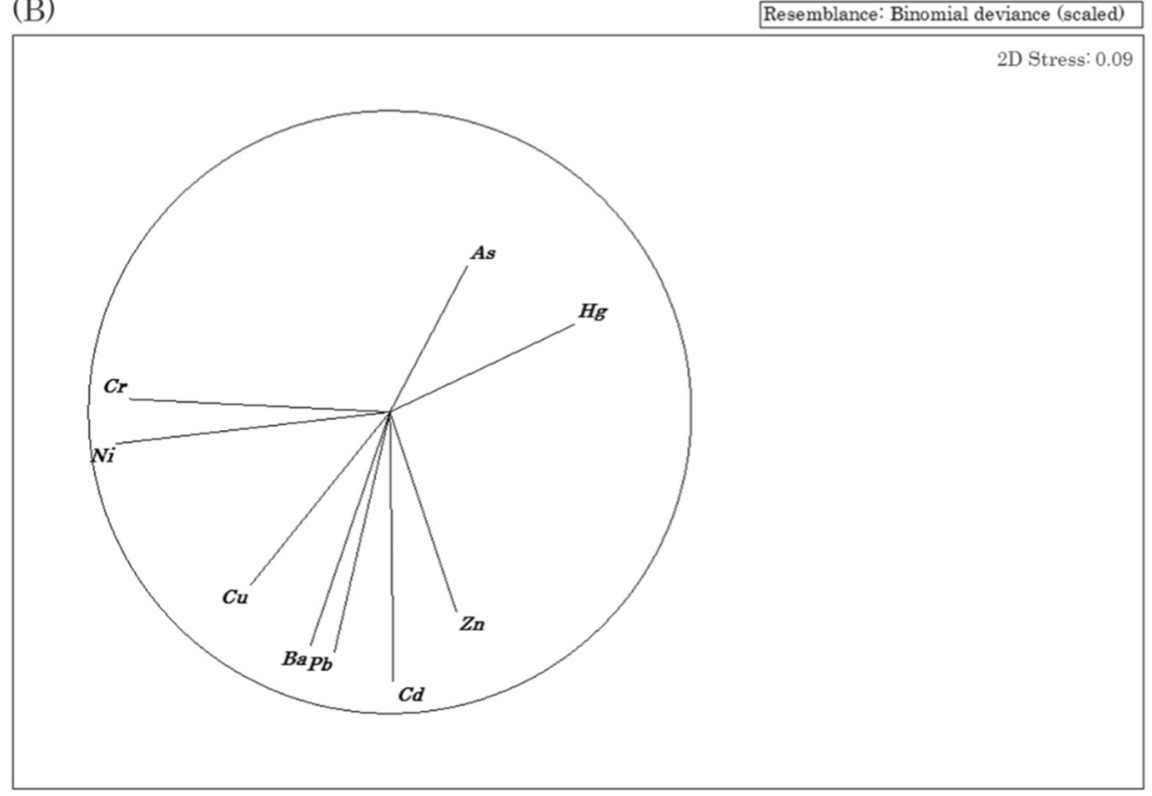

Fig. 4. (A) Two-dimensional nMDS ordination plot of trace element concentrations in the muscle of Scorpaena porcus according to sampling site (CB: Côte Bleue; PB: Prado Bay; PC: Plateau des Chèvres; and HY: Hyères); and (B) correlation vectors (binomial deviance resemblance) and 2D stress (0.09; good as $<.2$ ). Polygon ellipse lines are drawn for each size/age-class (white: juveniles; light gray: sub-adults; and dark gray: adults). Trace elements are indicated by sampling site symbols (white circle: $\mathrm{CB}$; light gray square: PB; gray diamond: PC; and black triangle: HY). in this species at all sampling sites, while $\delta^{13} \mathrm{C}$ values did not differ. The trophic level increase (estimated by $\delta^{15} \mathrm{~N}$ ) in larger and older individuals was linked to ontogenetic modifications of their diet, with the consumption of prey of increasing size and trophic level when growing (Harmelin-Vivien et al., 1989, this paper), along with morphological, physiological and growth rate differences between juvenile and adult fish (Perga and Grey, 2010). The increasing size of the mouth allows a broadening of the captured prey spectrum, resulting in the consumption of larger and more diverse prey, such as larger Caridea, Brachyoura and Teleostei (Bell and Harmelin-Vivien, 1983; Stergiou and Karpouzi, 2002; Chouvelon et al., 2014; Cresson et al., 2014b) in order to satisfy the increasing energy needs of the individuals (Harmelin-Vivien et al., 1989; Karpouzi and Stergiou, 2003).

The present study revealed major differences in TE concentrations with fish size/age class for most elements analyzed, while sex had no influence. Higher concentrations of $\mathrm{As}$ and $\mathrm{T}-\mathrm{Hg}$ were recorded in adults, and higher concentrations of $\mathrm{Ba}, \mathrm{Cd}, \mathrm{Cu}$, and $\mathrm{Pb}$ in juveniles and sub-adults, while no effect of fish size was observed for $\mathrm{Cr}, \mathrm{Ni}$, and $\mathrm{Zn}$. However, significant correlations between TE concentrations and size, age and $\delta^{15} \mathrm{~N}$ values of individuals were evident only for T-Hg, indicating that bioaccumulation during the life of $S$. porcus and biomagnification with its trophic level occurred only for $\mathrm{T}$ - $\mathrm{Hg}$. No significant correlations with size, age or trophic level was observed for all the other elements.

Our results on $\mathrm{T}-\mathrm{Hg}$ bioaccumulation and biomagnification were consistent with many studies that report positive correlations between $\delta^{15} \mathrm{~N}$ values or trophic level, and total or organic $\mathrm{Hg}$ in various marine organisms and food webs (Campbell et al., 2005; Magalhães et al., 2007; Ikemoto et al., 2008; Dierking et al., 2009; Nfon et al., 2009; Cossa et al., 2012; Harmelin-Vivien et al., 2012; Hao et al., 2013; Chouvelon et al., 2014). The absence of correlation between the concentrations of the other TEs and $S$. porcus descriptors $\left(\delta^{15} \mathrm{~N}\right.$ values, TL, age) indicated that they were neither biomagnified nor biodiminished during the fish ontogenetic development or through the food web. Similar results are reported in several studies (Ikemoto et al., 2008; Zhang and Wang, 2012; Hao et al., 2013), while other ones indicate a biodiminution of $\mathrm{As}, \mathrm{Cd}$ and $\mathrm{Pb}$ in freshwater and marine ecosystems (Asante et al., 2008). Some laboratory studies suggest that low assimilation 

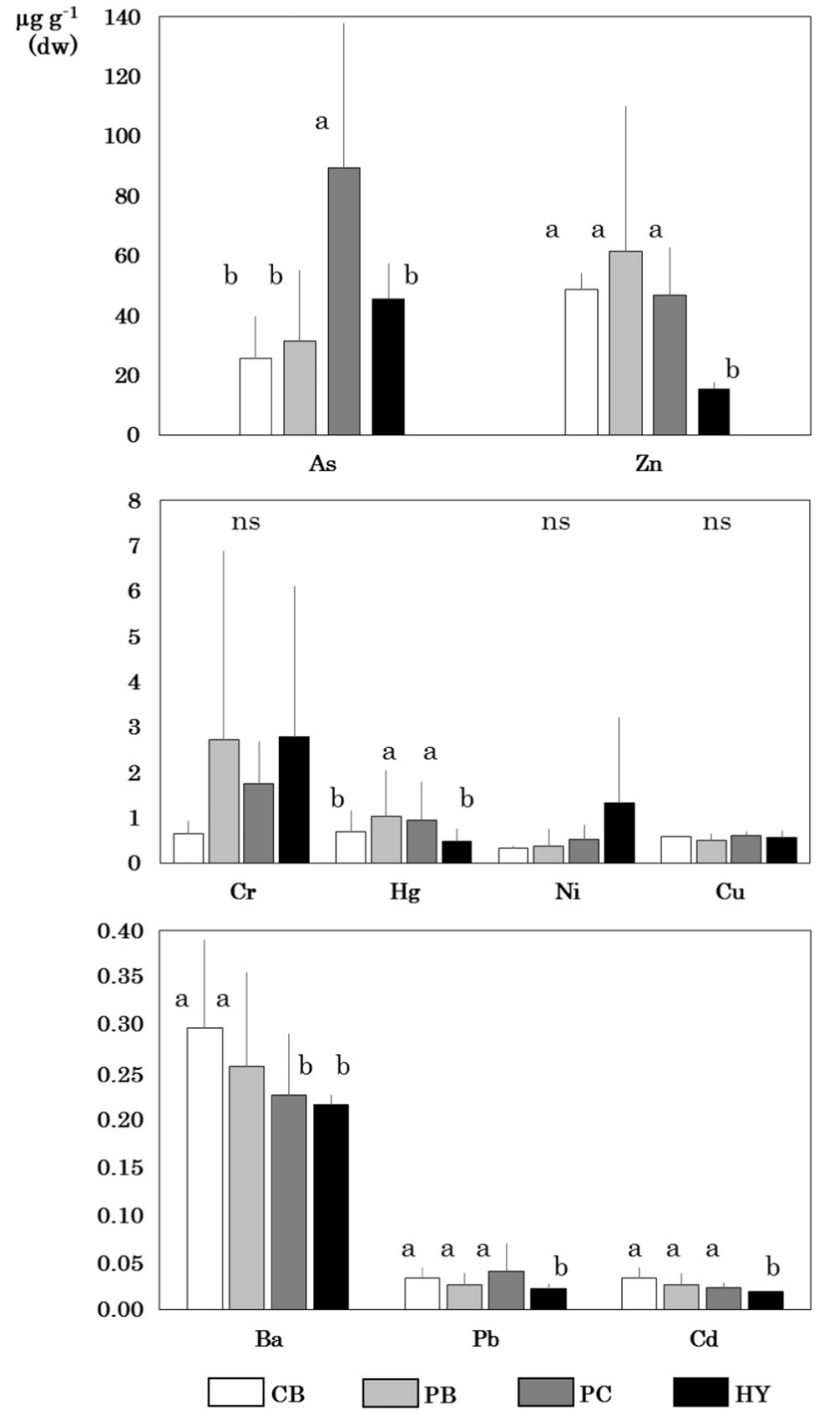

Fig. 5. Concentrations (Mean \pm SD) of the nine trace elements (TEs, $\mu \mathrm{g} \mathrm{g}^{-1} \mathrm{dw}$ ) in the muscle of Scorpaena porcus in the four sampling sites (in white, CB: Côte Bleue; in light gray, PB: Prado Bay; in dark gray, PC: Plateau de Chèvres; and in black, HY: Hyères). For convenience, TEs are ranked according to concentration ranges. Significant differences among sites are indicated by different letters (ns: not-significant, $p>.05$ ).

efficiencies and high efflux rates of $\mathrm{Cd}$ and $\mathrm{Pb}$ in marine organisms decrease their biomagnification potentials in food webs (Wang, 2002), while others find evidence of Cd biomagnification in food webs (Dietz et al., 2000). The same controversy is observed for the relationship of As concentration with $\delta^{15} \mathrm{~N}$ values in the North Pacific Ocean (Asante et al., 2008: biodiminution, versus Asante et al., 2010: biomagnification).

\subsection{Sanitary risk assumption}

Among the analyzed TEs, the European Commission only has set a limit for $\mathrm{Cd}, \mathrm{T}-\mathrm{Hg}$ and $\mathrm{Pb}(\mathrm{EC}, 2006)$ in seafood (Cd: $0.05 \mu \mathrm{g} \mathrm{g}^{-1}$ wet weight (ww); $\mathrm{Hg}$ : $0.5 \mu \mathrm{gg}^{-1} \mathrm{ww}$; and $\mathrm{Pb}$ : $0.3 \mu \mathrm{gg}^{-1}$ ww). T- $\mathrm{Hg}$ is of priority concern because of its neurotoxic, immunotoxic and teratogenic effects in vertebrates (Schlacher-Hoenlinger and Schlacher, 1998; Tartu et al., 2013). The values found in S. porcus from northwestern coastal sites in the present study for Cd $\left(0.135 \pm 0.092 \mu \mathrm{g} \mathrm{g}^{-1} \mathrm{ww}\right)$, $\mathrm{Hg}\left(0.004 \pm 0.001 \mu \mathrm{gg}^{-1} \mathrm{ww}\right)$ and $\mathrm{Pb}\left(0.005 \pm 0.003 \mu \mathrm{gg}^{-1} \mathrm{ww}\right)$ are lower than the limits defined by the European Commission in fish muscle (EC, 2006).

Comparison with data available in the literature indicates that TE concentrations found in the muscle of $S$. porcus at Marseille Bay and Hyères seagrass meadows were lower than or similar to the values reported for this species by Ulzuolu et al. (2007) in the Aegean Sea or other marine fish (predators of invertebrates and small fish) in the Mediterranean Sea (Harmelin-Vivien et al., 2009; Ennouri et al., 2013; Cresson et al., 2014a) and other regions (e.g., Monteiro et al., 1991; Miao et al., 2001; Metian et al., 2013; Briand et al., 2014). Concentrations in the muscle of $S$. porcus were not alarming. However, in order to assess the level of contamination for this species and the associated risk of consumption, additional analyses, i.e. speciation analyses of As and $\mathrm{Hg}$, and TEs in different parts of fish (e.g., liver), are required.

\section{Conclusion}

The analysis of the concentrations of nine trace elements (TEs), combined with the determination of diet, age, isotopic compositions and trophic level of the black scorpionfish Scorpaena porcus enabled the separation of local populations at four sampling sites submitted to different level of anthropic pressures in the northwestern Mediterranean Sea. Thus, $S$. porcus appears to be a good candidate for the monitoring of environmental contamination in coastal waters, given its sedentarity, predatory feeding behavior, high trophic level and its high abundance in Mediterranean coastal habitats. The risk of potential adverse effects through the consumption of $S$. porcus in the south of France appears to be limited, because the concentrations recorded are lower than the toxicological reference values (Cd, $\mathrm{Pb}$ and $\mathrm{Hg}$ ). However, significant bioaccumulation and bioamplification processes were observed for $\mathrm{T}-\mathrm{Hg}$ and were nearly significant for As but not for the other TEs analyzed. Large-scale monitoring studies of $S$. porcus could thus represent an appropriate tool to assess the contamination status of the environment by these two elements ( $\mathrm{Hg}$ and As), as well as their speciation, which present particular sanitary risks to human health associated with the consumption of seafood (Nadal et al., 2008; Lloret et al., 2016).

\section{Acknowledgments}

This study was carried out as a part of WP2 MERMEX-MISTRALS and is a contribution to the international IMBER and LOICZ projects. We are grateful to R. Sempéré, MERMEX co-PI, and to F. Carlotti and F. Van Wambeke, co-leaders of WP2 MERMEX, for helpful suggestions on the manuscript. This study forms part of the CONTAM project of M I O. This work was funded by the OHM "Littoral méditerranéen" project of the CNRS/AMU - DRIIHM LabEx. M. O. acknowledges financial support from the Provence-Alpes-Côte-d'Azur Region (PhD grant), the city of Marseille, and the Rhône-Mediterranean and Corsica Water Agency. Thanks are express to the Calanques National Park, Côte Bleue MPA and the fishermen of Hyères. The authors are grateful to the crews of the R/ V Antedon II and L'armandia and SAM-M I O platform for their operation at sea. We thank M. Brault-Fravou from the platform Analyses Elémentaires of LIENSs for her support in trace element analysis. The LIENSs laboratory acknowledges the CPER (Contrat de Projet EtatRégion) for funding the IR-MS, the ICPs and the AMA. The IUF (Institut Universitaire de France) is acknowledged for its support to PB. Finally, the authors are indebted to three anonymous reviewers for their detailed comments, improvements and helpful suggestions on a previous version of the manuscript.

\section{References}

Anderson, M.J., 2001. A new method for non-parametric multivariate analysis of variance. Austral Ecol. 26 (1), 32-46.

Anderson, M.J., Gorley, R.N., Clarke, K.R., 2008. PERMANOVA + for PRIMER: Guide to Software and Statistical Methods. PRIMER-E, Plymouth, UK.

Angeletti, R., Binato, G., Guidotti, M., Morelli, S., Pastorelli, A.A., Sagratella, E., Ciardullo, S., Stacchini, P., 2014. Cadmium bioaccumulation in Mediterranean spider 
crab (Maya squinado): Human consumption andhealth implications for exposure in Italian population. Chemosphere 100, 83-88.

Arfi, R., Arnoux, A., Bellan-Santini, D., Bellan, G., Laubier, L., Pergent-Martini, C., 2000. Cortiou: évolution d'un site marin soumis à un rejet urbain. Synthèse bibliographique 1960-2000. Centre d'Océanologie de Marseille Publisher, 38p.

Asante, K.A., Agusa, T., Kubota, R., Mochizuki, H., Ramu, K., Nishida, S., Ohta, S., Yeh, H., Subramanian, A., Tanabe, S., 2010. Trace elements and stable isotope ratios ( $\delta 13$ $\mathrm{C}$ and $\delta 15 \mathrm{~N}$ ) in fish from deep-waters of the Sulu Sea and the Celebes Sea. Mar. Pollut. Bull. 60 (9), 1560-1570.

Asante, K.A., Agusa, T., Mochizuki, H., Ramu, K., Inoue, S., Kubodera, T., Takahashi, S., Subramanian, A., Tanabe, S., 2008. Trace elements and stable isotopes $\left(\delta^{13} \mathrm{C}\right.$ and $\delta^{15} \mathrm{~N}$ ) in shallow and deep-water organisms from the East China Sea. Environ. Pollut. 156 (3), 862-873.

Authman, M.M.N., Abbas, W.T., Gaafar, A.Y., 2012. Metals concentrations in Nile tilapia Oreochromis niloticus (Linnaeus, 1758) from illegal fish farm in Al-Minufiya Province, Egypt, and their effects on some tissues structures. Ecotoxicol. Environ. Saf. 84, 163-172.

Bell, J., Harmelin-Vivien, M.L., 1982. Fish fauna of French Mediterranean Posidonia oceanica seagrass meadows. I: Community structure. Tethys 10 (4), 337-347.

Bell, J., Harmelin-Vivien, M.L., 1983. Fish fauna of French Mediterranean Posidonia oceanica seagrass meadows. II: Feeding habits. Tethys 11 (1), 1-14.

Bellan, G., 1970. Pollution by sewage in Marseille. Mar. Pollut. Bull. 1 (4), 59-60.

Bellan, G., Bellan-Santini, D., Picard, J., 1980. Mise en évidence de modèles éco-biologiques dans des zones soumises à pertubations par matières organiques. Oceanol. Acta 3 (3), 383-390.

Bethoux, J.P., Gentili, B., Morin, P., Nicolas, E., Pierre, C., Ruiz-Pino, D., 1999. The Mediterranean Sea: a miniature ocean for climatic and environmental studies and a key for the climatic functioning of the North Atlantic. Prog. Oceanogr. 44, 131-146.

Bonito, L.T., Hamdoun, A., Sandin, S.A., 2016. Evaluation of the global impacts of mitigation on persistent, bioaccumulative and toxic pollutants in marine fish. PeerJ 4, e1573.

Bonnard, N., Brondeau, M.T., Falcy, M., Jargot, D., Lafon, D., Robert, S., Schneider, O., Serre, P., 2012. Zinc et composés minéraux. Fiche toxicologique FT 75 INRS, édition 2012, 12p.

Bosch, A.C., O'neill, B., Sigge, G.O., Kerwath, S.E., Hoffman, L.C., 2016. Heavy metals in marine fish meat and consumer health: a review. J. Sci. Food Agric. 96, 32-48.

Briand, M.J., Letourneur, Y., Bonnet, X., Wafo, E., Fauvel, T., Brischoux, F., Guillou, G., Bustamante, P., 2014. Spatial variability of metallic and organic contamination of anguilliform fish in New Caledonia. Environ. Sci. Pollut. Res. 21 (6), 4576-4591.

Bury, N.R., Walker, P.A., Glover, C.N., 2003. Nutritive metal uptake in teleost fish. J. Exp. Biol. 206, 11-23.

Bustamante, P., Lahaye, V., Durnez, C., Churlaud, C., Caurant, F., 2006. Total and organic $\mathrm{Hg}$ concentrations in cephalopods from the North Eastern Atlantic waters: influence of geographical origin and feeding ecology. Sci. Total Environ. 368 (2), 585-596.

Campbell, L.M., Norstrom, R.J., Hobson, K.A., Muir, D.C.G., Backus, S., Fisk, A.T., 2005. Mercury and other trace elements in a pelagic Arctic marine food web (Northwater Polynya, Baffin Bay). Sci. Total Environ. 351-352, 247-263.

Canli, M., Atli, G., 2003. The relationships between heavy metal (Cd, Cr, Cu, Fe, Pb, Zn) levels and the size of six Mediterranean fish species. Environ. Pollut. 121 (1), 129-136.

Castro-González, M.I., Méndez-Armenta, M., 2008. Heavy metals: implications associated to fish consumption. Environ. Toxicol. Pharmacol. 26, 263-271.

Cathalot, C., Rabouille, C., Tisnérat-Laborde, N., Toussaint, F., Kerhervé, P., Buscail, R., Loftis, K., Sun, M.Y., Tronczynski, J., Azoury, S., Lansard, B., Treignier, C., Pastor, L., Tesi, T., 2013. The fate of river organic carbon in coastal areas: A study in the Rhône River delta using multiple isotopic $\left(\delta^{13} \mathrm{C}, \Delta{ }^{14} \mathrm{C}\right)$ and organic tracers. Geochim. Cosmochim. Acta 118, 33-55.

Chouvelon, T., Caurant, F., Cherel, Y., Simon-Bouhet, B., Spitz, J., Bustamante, P. 2014. Species-and size-related patterns in stable isotopes and mercury concentrations in fish help refine marine ecosystem indicators and provide evidence for distinct management units for hake in the Northeast Atlantic. ICES J. Mar. Sci.: Journal du Conseil, fst199.

Clarke, K.R., 1993. Non-parametric multivariate analyses of changes in community structure. Aust. J. Ecol. 18 (1), 117-143.

Clarke, K.R., Gorley, R.N., 2006. Change in Marine Communities: An Approach to Statistical Analysis and Interpretation. PRIMER-E Ltd, Plymouth.

Cobelo-García, A., Prego, R., Labandeira, A., 2004. Land inputs of trace metals, major elements, particulate organic carbon and suspended solids to an industrial coastal bay of the NE Atlantic. Water Res. 38, 1753-1764.

Copat, C., Arena, G., Fiore, M., Ledda, C., Fallico, R., Sciacca, S., Ferrante, M., 2013. Heavy metals concentrations in fish and shellfish from eastern Mediterranean Sea: Consumption advisories. Food Chem. Toxicol. 53, 33-37.

Copat, C., Maggiore, R., Arena, G., Lanzafame, S., Fallico, R., Salvatore, S.A., Ferrante, M., 2012. Evaluation of a temporal trend heavy metals contamination in Posidonia oceanica (L.) Delile, (1813) along the western coastline of Sicily (Italy). J. Environ. Monit. 14 (1), 187-192.

Cossa, D., Fanget, A.S., Chiffoleau, J.F., Bassetti, M.A., Buscail, R., Dennielou, B., Briggs, K., Arnaud, M., Guédron, S., Berné, S., 2017. Chronology and sources of trace elements accumulation in the Rhône pro-delta sediments (Northwestern Mediterranean) during the last 400 years. Progress Oceanogr. (this issue).

Cossa, D., Harmelin-Vivien, M.L., Mellon-Duval, C., Loizeau, V., Averty, B., Crochet, S. Chou, L., Cadiou, J.F., 2012. Influences of bioavailability, trophic position, and growth on methylmercury in hakes (Merluccius merluccius) from Northwestern Mediterranean and Northeastern Atlantic. Environ. Sci. Technol. 46 (9), 4885-4893.

Cresson, P., Bouchoucha, M., Miralles, F., Elleboode, R., Mahé, K., Marusczak, N., Thebault, H., Cossa, D., 2015a. Are red mullet efficient as bio-indicators of mercury contamination? A case study from the French Mediterranean. Mar. Pollut. Bull. 91 (1), 191-199.

Cresson, P., Bouchoucha, M., Morat, F., Miralles, F., Chavanon, F., Loizeau, V., Cossa, D., 2015b. A multitracer approach to assess the spatial contamination pattern of hake (Merluccius merluccius) in the French Mediterranean. Sci. Total Environ. 532, 184-194.

Cresson, P., Fabri, M.C., Bouchoucha, M., Brach Papa, C., Chavanon, F., Jadaud, A., Knoery, J., Miralles, F., Cossa, D., 2014a. Mercury in organisms from the Northwestern Mediterranean slope: importance of food sources. Sci. Total Environ. 497-498, 229-238.

Cresson, P., Ruitton, S., Fontaine, M.F., Harmelin-Vivien, M.L., 2012. Spatio-temporal variation of suspended and sedimentary organic matter quality in the Bay of Marseilles (NW Mediterranean) assessed by biochemical and isotopic analyses. Mar. Pollut. Bull. 64 (6), 1112-1121.

Cresson, P., Ruitton, S., Ourgaud, M., Harmelin-Vivien, M.L., 2014b. Contrasting perception of fish trophic level from stomach content and stable isotope analyses: a Mediterranean artificial reef experience. J. Exp. Mar. Biol. Ecol. 452, 54-62.

Darnaude, A.M., Salen-Picard, C., Polunin, N.V., Harmelin-Vivien, M.L., 2004 Trophodynamic linkage between river runoff and coastal fishery yield elucidated by stable isotope data in the Gulf of Lions (NW Mediterranean). Oecologia 138 (3), 325-332.

Demirhan, S.A., Can, M.F., 2009. Age, growth and food composition of Scorpaena porcus (Linnaeus, 1758) in the southeastern Black Sea. J. Appl. Ichthyol. 25 (2), 215-218.

Dietz, R., Riget, F., Cleemann, M., Aarkrog, A., Johansen, P., Hansen, J.C., 2000. Comparison of contaminants from different trophic levels and ecosystems. Sci. Total Environ. 245 (1), 221-231.

Dierking, J., Wafo, E., Schembri, T., Lagadec, V., Nicolas, C., Letourneur, Y., HarmelinVivien, M.L., 2009. Spatial patterns in PCBs, pesticides, mercury and cadmium in the common sole in the NW Mediterranean Sea, and a novel use of contaminants as biomarkers. Mar. Pollut. Bull. 58 (11), 1605-1614.

Domingo, J.L., Bocio, A., Falcó, G., Llobet, J.M., 2007. Benefits and risks of fish consumption: Part I. A quantitative analysis of the intake of omega-3 fatty acids and chemical contaminants. Toxicology 230 (2), 219-226.

EC, 2006. European Commission. Règlement de la Commission des Communautés Européennes, No 1881/2006 de la commission du 19 décembre 2006 portant fixation de teneurs maximales pour certains contaminants dans les denrées alimentaires. Journal Officiel de l'Union Européenne, 96p.

Elbaz-Poulichet, F., 2005. River Inputs of Metals and Arsenic. In the Mediterranean Sea. Springer-Verlag, Berlin Heidelberg, pp. 211-235.

Ennouri, R., Mili, S., Chouba, L., 2013. Metallic contamination of Red Mullet (Mullus barbatus) and Round Sardinella (Sardinella aurita) from the Gulf of Tunis/La contamination metallique du rouget de vase (Mullus barbatus) et de la sardinelle (Sardinella aurita) du golfe de tunis. Cybium. Int. J. Ichthyol. 37 (1-2), 49-59.

Faget, D., 2009. Le milieu marin méditerranéen: conflits, usages et représentations: le cas du golfe de Marseille (début XVIIIe-début XXe siècles). Aix Marseille 1, 560p.

Falcy, M., Jargot, D., La Rocca, B., Pillière, F., Robert, S., Serre, P., Simonnard, A., 2014 Mercure et composés minéraux. Fiche toxicologique FT 55 INRS, 14p.

FAO, 2012. The state of world fisheries and aquaculture 2012. Rome. 209p.

Fleeger, J.W., Carman, K.R., Nisbet, R.M., 2003. Indirect effects of contaminants in aquatic ecosystems. Sci. Total Environ. 317 (1), 207-233.

Fraysse, M., Pairaud, I., Ross, O.N., Faure, V.M., Pinazo, C., 2014. Intrusion of Rhône River diluted water into the Bay of Marseille: generation processes and impacts on ecosystem functioning. J. Geophys. Res. Oceans 119 (10), 6535-6556.

Hall, B.D., Bodaly, R.A., Fudge, R.J.P., Rudd, J.W.M., Rosenberg, D.M., 1997. Food as the dominant pathway of methylmercury uptake by fish. Water Air Soil Pollut. 100 (1-2), 13-24.

Halpern, B.S., Walbridge, S., Selkoe, K.A., Kappel, C.V., Micheli, F., D'Agrosa, C., Bruno, J.F., Casey, K.S., Ebert, C., Fox, H.E., 2008. A global map of human impact on marine ecosystems. Science 319 (5865), 948-952.

Hao, Y., Chen, L., Zhang, X., Zhang, D., Zhang, X., Yu, Y., Fu, J., 2013. Trace elements in fish from Taihu Lake, China: Levels, associated risks, and trophic transfer. Ecotoxicol. Environ. Saf. 90, 89-97.

Harmelin-Vivien, M.L., 1981. Description d'un petit chalut à perche pour récolter la faune vagile des herbiers de posidonies. Rapport et procès verbaux de la Commission internationale pour l'Exploration Scientifique de la Mer Méditerranée 27 (5), 199-200.

Harmelin-Vivien, M.L., 1982. Ichtyofaune des herbiers de posidonies du Parc national de Port-Cros: 1. Composition et variations spatio-temporelles. Travaux Scientifiques du Parc national de Port-Cros (France) 8, 69-92.

Harmelin-Vivien, M.L., Bodiguel, X., Charmasson, S., Loizeau, V., Mellon-Duval, C. Tronczyński, J., Cossa, D., 2012. Differential biomagnification of PCB, PBDE, Hg and Radiocesium in the food web of the European hake from the NW Mediterranean. Mar. Pollut. Bull. 64 (5), 974-983.

Harmelin-Vivien, M.L., Cossa, D., Crochet, S., Bănaru, D., Letourneur, Y., Mellon-Duval, C., 2009. Difference of mercury bioaccumulation in red mullets from the northwestern Mediterranean and Black seas. Mar. Pollut. Bull. 58 (5), 679-685.

Harmelin-Vivien, M.L., Loizeau, V., Mellon, C., Beker, B., Arlhac, D., Bodiguel, X. Ferraton, F., Hermand, R., Philippon, X., Salen-Picard, C., 2008. Comparison of C and $\mathrm{N}$ stable isotope ratios between surface particulate organic matter and microphytoplankton in the Gulf of Lions (NW Mediterranean). Cont. Shelf Res. 28 (15), 1911-1919.

Harmelin-Vivien, M.L., Kaim-Malka, R., Ledoyer, M., Jacob-Abraham, S., 1989. Food partitioning among scorpaenid fishes in Mediterranean seagrass beds. J. Fish Biol. 34 (5), 715-734.

Has-Schön, E., Bogut, I., Strelec, I., 2006. Heavy Metal Profile in Five Fish Species Included in Human Diet, Domiciled in the End Flow of River Neretva (Croatia). Arch. Environ. Contam. Toxicol. 50, 545-551. 
Heimbürger, L.-E., Migon, C., Dufour, A., Chiffoleau, J.-F., Cossa, D., 2010. Trace metal concentrations in the North-western Mediterranean atmospheric aerosol between 1986 and 2008: seasonal patterns and decadal trends. Sci. Total Environ. 408, 2629-2638.

Hu, Y., Liu, X., Bai, J., Shih, K., Zeng, E.Y., Cheng, H., 2013. Assessing heavy metal pollution in the surface soils of a region that had undergone three decades of intense industrialization and urbanization. Environ. Sci. Pollut. Res. 20, 6150-6159.

Ikemoto, T., Tu, N.P.C., Okuda, N., Iwata, A., Omori, K., Tanabe, S., Tuyen, B.C. Takeuchi, I., 2008. Biomagnification of trace elements in the aquatic food web in the Mekong Delta, South Vietnam using stable carbon and nitrogen isotope analysis. Arch. Environ. Contam. Toxicol. 54 (3), 504-515.

Karpouzi, V.S., Stergiou, K.I., 2003. The relationships between mouth size and shape and body length for 18 species of marine fishes and their trophic implications. J. Fish Biol. 62 (6), 1353-1365

Kim, H.Y., Kim, J.C., Kim, S.Y., Lee, J.H., Jang, Y.M., Lee, M.S., Park, J.S., Lee, K.H., 2007a. Monitoring of heavy metals in fishes in Korea-As, Cd, Cu, Pb, Mn, Zn, Total Hg. Korean J. Food Sci. Technol. 39, 353-359.

Kim, J.-H., Ludwig, W., Schouten, S., Kerhervé, P., Herfort, L., Bonnin, J., Sinninghe Damsté, J.S., 2007b. Impact of flood events on the transport of terrestrial organic matter to the ocean: a study of the Têt River (SW France) using the BIT index. Org. Geochem. 38, 1593-1606.

Lafabrie, C., Pergent, G., Kantin, R., Pergent Martini, C., Gonzalez, J.L., 2007. Trace metals assessment in water, sediment, mussel and seagrass species - validation of the use of Posidonia oceanica as a metal biomonitor. Chemosphere 68 (11), 2033-2039.

Lafabrie, C., Pergent, G., Pergent Martini, C., 2009. Utilization of the seagrass Posidonia oceanica to evaluate the spatial dispersion of metal contamination. Sci. Total Environ. 407 (7), 2440-2446.

La Mesa, M., La Mesa, G., Micalizzi, M., 2005. Age and growth of Madeira scorpionfish, Scorpaena maderensis Valenciennes, 1833, in the central Mediterranean. Fish. Res. 74 (1-3), 265-272.

Legendre, P., Legendre, L.F., 2012. Numerical Ecology. Elsevier (Ed.), Third English ed. Eastbourne, UK, 990p.

Leleu, K., Pelletier, D., Charbonnel, E., Letourneur, Y., Alban, F., Bachet, F., Boudouresque, C.F., 2014. Métiers, effort and catches of a Mediterranean small-scale coastal fishery: the case of the Côte Bleue Marine Park. Fish. Res. 154, 93-101.

Lloret, J., Rätz, H.-J., Lleonart, J., Demestre, M., 2016. Challenging the links between seafood and human health in the context of global change. J. Mar. Biol. Assoc. 96 (1), $29-42$.

Luoma, S.N., Hogstrand, C., Bell, R.A., Bielmyer, G.K., Galvez, F., LeBlanc, G.A., Lee, B.G., Purcell, T.W., Santore, R.C., Santschi, P.H., Shaw, J.R., 2002. Biological processes. In: Andren, A.W., Bober, T.W. (Eds.), Silver in the Environment: Transport, Fate, and Effects. SETAC, Pensacola, FL, USA, pp. 65-95.

MacDonald, R., Mackay, D., Hickie, B., 2002. A new approach suggests that phenomena, such as bioconcentration, biomagnification, and bioaccumulation, result from two fundamental processes. Environ. Sci. Technol. 36 (23), 457.

Magalhães, M.C., Costa, V., Menezes, G.M., Pinho, M.R., Santos, R.S., Monteiro, L.R., 2007. Intra- and inter-specific variability in total and methylmercury bioaccumulation by eight marine fish species from the Azores. Mar. Pollut. Bull. 54 (10), $1654-1662$

Martorell, I., Perelló, G., Martí-Cid, R., Llobet, J.M., Castell, V., Domingo, J.L., 2011. Human exposure to arsenic, cadmium, mercury, and lead from foods in Catalonia, Spain: temporal trend. Biol. Trace Elem. Res. 142 (3), 309-322.

Massutí, E., Morales-Nin, B., Moranta, J., 2000. Growth variability of blue-mouth Helicolenus dactylopterus (Osteichthyes: Scorpaenidae) in two western Mediterranean areas: Alboran Sea and Balearic Sea. Fish. Res. 46, 165-176.

Mathews, T., Fisher, N.S., 2009. Dominance of dietary intake of metals in marine elasmobranch and teleost fish. Sci. Total Environ. 407, 5156-5161.

Matthai, C., Birch, G.F., Bickford, G.P., 2002. Anthropogenic trace metals in sediment and settling particulate matter on a high-energy continental shelf (Sydney, Australia). Mar. Environ. Res. 54, 99-127.

Matthiessen, P., Reed, J., Johnson, M., 1999. Sources and Potential Effects of Copper and Zinc Concentrations in the Estuarine Waters of Essex and Suffolk, United Kingdom. Mar. Pollut. Bull. 38, 908-920.

McArdle, B.H., Anderson, M.J., 2001. Fitting multivariate models to community data: a comment on distance-based redundancy analysis. Ecology 82 (1), 290-297.

Merciai, R., Guasch, H., Kumar, A., Sabater, S., García-Berthou, E., 2014. Trace metal concentration and fish size: Variation among fish species in a Mediterranean river. Ecotoxicol. Environ. Saf. 107, 154-161.

Metian, M., Warnau, M., Chouvelon, T., Pedraza, F., Rodriguez y Baena, A.M. Bustamante, P., 2013. Trace element bioaccumulation in reef fish from New Caledonia: influence of trophic groups and risk assessment for consumers. Mar. Environ. Res. 87-88, 26-36.

Miao, X.S., Ann Woodward, L., Swenson, C., Li, Q.X., 2001. Comparative concentrations of metals in marine species from french frigate shoals, North Pacific Ocean. Mar Pollut. Bull. 42 (11), 1049-1054.

Migon, C., Sandroni, V., Marty, J.C., Gasser, B., Miquel, J.C., 2002. Transfer of atmospheric matter through the euphotic layer in the northwestern Mediterranean: seasonal pattern and driving forces. Deep Sea Res. Part II 49 (21), 2125-2141.

Millot, C., 1999. Circulation in the Western Mediterranean Sea. J. Mar. Syst. 20, 423-442.

Miniero, R., Abate, V., Brambilla, G., Davoli, E., De Felip, E., De Filippis, S.P., Dellatte, E., De Luca, S., Fanelli, R., Fattore, E., Ferri, F., Fochi, I., Rita Fulgenzi, A., Iacovella, N., Iamiceli, A.L., Lucchetti, D., Melotti, P., Moret, I., Piazza, R., Roncarati, A., Ubaldi, A., Zambon, S., Di Domenico, A., 2014. Persistent toxic substances in Mediterranean aquatic species. Sci. Total Environ. 494-495, 18-27.

Monteiro, L., Isidro, E., Lopes, H., 1991. Mercury content in relation to sex, size, age and growth in two scorpionfish (Helicolenus dactylopterus and Pontinus kuhlii) from
Azorean waters. Water Air Soil Pollut. 56 (1), 359-367.

Naccari, C., Cicero, N., Ferrantelli, V., Giangrosso, G., Vella, A., Macaluso, A., Naccari, F., Dugo, G., 2015. Toxic metals in pelagic, benthic and demersal fish species from Mediterranean FAO Zone 37. Bull. Environ. Contam. Toxicol. 95 (5), 567-573.

Nadal, M., Ferre-Huguet, N., Marti-Cid, R., Schuhmacher, M., Domingo, J.L., 2008. Exposure to metals through the consumption of fish and seafood by the population living near the Ebro River in Catalonia, Spain: health risks. Hum. Ecol. Risk Assess. 14 (4), 780-795.

Newsome, S.D., Martinez Del Rio, C., Bearhop, S., Phillips, D.L., 2007. A niche for isotopic ecology. Front. Ecol. Environ. 5, 429-436.

Nfon, E., Cousins, I.T., Järvinen, O., Mukherjee, A.B., Verta, M., Broman, Da., 2009. Trophodynamics of mercury and other trace elements in a pelagic food chain from the Baltic Sea. Sci. Total Environ. 407 (24), 6267-6274.

Ourgaud, M., Ruitton, S., Bell, J.D., Letourneur, Y., Harmelin, J.G., Harmelin-Vivien, M.L., 2015. Response of a seagrass fish assemblage to improved wastewater treatment. Mar. Pollut. Bull. 90 (1), 25-32.

Oursel, B., Garnier, C., Durrieu, G., Mounier, S., Omanović, D., Lucas, Y., 2013. Dynamics and fates of trace metals chronically input in a Mediterranean coastal zone impacted by a large urban area. Mar. Pollut. Bull. 69 (1-2), 137-149.

Perez, T., Longet, D., Schembri, T., Rebouillon, P., Vacelet, J., 2005. Effects of 12 years' operation of a sewage treatment plant on trace metal occurrence within a Mediterranean commercial sponge (Spongia officinalis, Demospongiae). Mar. Pollut. Bull. 50 (3), 301-309.

Perga, M.E., Grey, J., 2010. Laboratory measures of isotope discrimination factors: comments on Caut, Angulo and Courchamp (2008, 2009). J. Appl. Ecol. 47 (4), 942-947.

Pergent, G., Pergent-Martini, C., 1999. Mercury levels and fluxes in Posidonia oceanica meadows. Environ. Pollut. 106 (1), 33-37.

Pergent-Martini, C., 1998. Posidonia oceanica: a biological indicator of past and present mercury contamination in the Mediterranean Sea. Mar. Environ. Res. 45 (2), 101-111.

Personnic, S., Boudouresque, C.-F., Astruch, P., Ballesteros, E., Blouet, S., Bellan-Santini, D., Bonhomme, P., Thibault-Botha, D., Feunteun, E., Harmelin-Vivien, M.L., Pergent, G., Pergent-Martini, C., Pastor, J., Poggiale, J.C., Renaud, F., Thibaut, T., Ruitton, S., 2014. An ecosystem-based approach to assess the status of a Mediterranean ecosystem, the Posidonia oceanica seagrass meadow. PLoS One 9 (6), e98994.

Petrenko, A., Leredde, Y., Marsaleix, P., 2005. Circulation in a stratified and wind-forced Gulfof Lions, NW Mediterranean Sea: in situ and modeling data. Cont. Shelf Res. 25 (1), 7-27.

Pinkas, L., Oliphant, M.S., Iverson, I.L.K., 1971. Food habits of albacore, bluefin tuna, and bonito in California waters. Fish. Bull. 152, 11-105.

Pinnegar, J.K., Polunin, N.V.C., 1999. Differential fractionation of $\delta^{13} \mathrm{C}$ and $\delta^{15} \mathrm{~N}$ among fish tissues: implications for the study of trophic interactions. Funct. Ecol. 13 (2), 225-231.

Pouil, S., Oberhänsli, F., Bustamante, P., Metian, M., 2017. Dietary Zn and the subsequent organotropism in fish: no influence of food quality, frequency of feeding and environmental conditions ( $\mathrm{pH}$ and temperature). Chemosphere 183, 503-509.

Rastorgueff, P.A., Harmelin-Vivien, M.L., Richard, P., Chevaldonné, P., 2011. Feeding strategies and resource partitioning mitigate the effects of oligotrophy for marine cave mysids. Mar. Ecol. Prog. Ser. 440, 163-176.

Riera, P., Richard, P., 1997. Temporal variation of $\delta^{13} \mathrm{C}$ in particulate organic matter and oyster Crassostrea gigas in Marennes-Oléron Bay (France): effect of freshwater inflow. Oceanogr. Lit. Rev. 8 (44), 844.

Salminen, R., Batista, M.J., Bidovec, M., Demetriades, A., De Vivo, B., De Vos, W., Duris, M., Gilucis, A., Gregorauskiene, V., Halamic, J., Heitzmann, P., Lima, A., Jordan, G., Klaver, G., Klein, P., Lis, J., Locutura, J., Marsina, K., Mazreku, A., O'Connor, P.J., Olsson, S.̊., Ottesen, R., Petersell, V., Plant, J.A., Reeder, S., Salpeteur, I., Sandstr $€$ €om, H., Siewers, U., Steenfelt, A., Tarvainen, T., 2005. Geochemical Atlas of Europe. Part I: Background Information, Methodology and Maps.

Scarcella, G., Grati, F., Polidori, P., Domenichetti, F., Bolognini, L., Fabi, G., 2011. Comparison of growth rates estimated by otolith reading of Scorpaena porcus and Scorpaena notata caught on artificial and natural reefs of the northern Adriatic sea. Braz. J. Oceanogr. 59 (SPE1), 33-42.

Schlacher-Hoenlinger, M.A., Schlacher, T.A., 1998. Accumulation, contamination, and seasonal variability of trace metals in the coastal zone-patterns in a seagrass meadow from the Mediterranean. Mar. Biol. 131 (3), 401-410.

Schroeder, H.A., Darrow, D.K., 1972. Relation of trace metals to human health. Boston College Environ. Affairs Law Rev. 2, 222p.

Sebastiano, M., Bustamante, P., Costantini, D., Eulaers, I., Malarvannan, G., MendezFernandez, P., Churlaud, C., Blévin, P., Hauselmann, A., Dell'omo, G., Covaci, A., Eens, M., Chastel, O., 2016. High levels of mercury and low levels of persistent organic pollutants in a tropical seabird in French Guiana, the Magnificent frigatebird, Fregata magnificens. Environ. Pollut. 214, 384-393.

Sempéré, R., Charrière, B., Van Wambeke, F., Cauwet, G., 2000. Carbon inputs of the Rhône River to the Mediterranean Sea: biogeochemical implications. Global Biogeochem. Cycles 14 (2), 669-681.

Stergiou, K.I., Karpouzi, V.S., 2002. Feeding habits and trophic levels of Mediterranean fish. Rev. Fish Biol. Fish. 11 (3), 217-254.

Storelli, M.M., 2008. Potential human health risks from metals ( $\mathrm{Hg}, \mathrm{Cd}$, and $\mathrm{Pb}$ ) and polychlorinated biphenyls (PCBs) via seafood consumption: estimation of target hazard quotients (THQs) and toxic equivalents (TEQs). Food Chem. Toxicol. 46 (8), 2782-2788.

Sweeting, C., Polunin, N., Jennings, S., 2006. Effects of chemical lipid extraction and arithmetic lipid correction on stable isotope ratios of fish tissues. Rapid Commun. Mass Spectrom. 20 (4), 595-601.

Tartu, S., Goutte, A., Bustamante, P., Angelier, F., Moe, B., Clément-Chastel, C., Bech, C., 
Gabrielsen, G.W., Bustnes, J.O., Chastel, O., 2013. To breed or not to breed: endocrine response to mercury contamination by an Arctic seabird. Biol. Lett. 9 (4), 20130317.

The MERMEX Group, Durrieu de Madron, X., Guieu, C., Sempéré, R., Conan, P., Cossa, D., D’Ortenzio, F., Estournel, C., Gazeau, F., Rabouille, C., Stemmann, L., Bonnet, S., Diaz, F., Koubbi, P., Radakovitch, O., Babin, M., Baklouti, M., Bancon-Montigny, C., Belviso, S., Bensoussan, N., Bonsang, B., Bouloubassi, I., Brunet, C., Cadiou, J.F., Carlotti, F., Chami, M., Charmasson, S., Charrière, B., Dachs, J., Doxaran, D., Dutay, J.C., Elbaz-Poulichet, F., Eléaume, M., Eyrolles, F., Fernandez, C., Fowler, S.,

Francour, P., Gaertner, J.C., Galzin, R., Gasparini, S., Ghiglione, J.F., Gonzalez, J.L., Goyet, C., Guidi, L., Guizien, K., Heimbürger, L.E., Jacquet, S.H.M., Jeffrey, W.H., Joux, F., Le Hir, P., Leblanc, K., Lefèvre, D., Lejeusne, C., Lemé, R., Loÿe-Pilot, M.D., Mallet, M., Méjanelle, L., Mélin, F., Mellon, C., Mérigot, B., Merle, P.L., Migon, C., Miller, W.L., Mortier, L., Mostajir, B., Mousseau, L., Moutin, T., Para, J., Pérez, T., Petrenko, A., Poggiale, J.C., Prieur, L., Pujo-Pay, M., Pulido, V., Raimbault, P., Rees, A.P., Ridame, C., Rontani, J.F., Ruiz Pino, D., Sicre, M.A., Taillandier, V., Tamburini, C., Tanaka, T., Taupier-Letage, I., Tedetti, M., Testor, P., Thébault, H., Thouvenin, B., Touratier, F., Tronczynski, J., Ulses, C., Van Wambeke, F., Vantrepotte, V., Vaz, S., Verney, R., 2011. Marine ecosystems' responses to climatic and anthropogenic forcings in the Mediterranean. Prog. Oceanogr. 91 (2), 97-166.

Tomasello, B., Copat, C., Pulvirenti, V., Ferrito, V., Ferrante, M., Renis, M., Sciacca, S. Tigano, C., 2012. Biochemical and bioaccumulation approaches for investigating marine pollution using Mediterranean rainbow wrasse, Coris julis (Linneaus 1798). Ecotoxicol. Environ. Saf. 86, 168-175.

Uluozlu, O.D., Tuzen, M., Mendil, D., Soylak, M., 2007. Trace metal content in nine species of fish from the Black and Aegean Seas, Turkey. Food Chem. 104 (2), 835-840.

Velusamy, A., Satheesh Kumar, P., Ram, A., Chinnadurai, S., 2014. Bioaccumulation of heavy metals in commercially important marine fishes from Mumbai Harbor, India.
Mar. Pollut. Bull. 81, 218-224.

Vieira, C., Morais, S., Ramos, S., Delerue-Matos, C., Oliveira, M.B.P.P., 2011. Mercury, cadmium, lead and arsenic levels in three pelagic fish species from the Atlantic Ocean: intra- and inter-specific variability and human health risks for consumption. Food Chem. Toxicol. 49, 923-932.

Vieira, H., Morgado, F., Soares, A., Abreu, S., 2015. Fish consumption recommendation to conform to current advice in regard to mercury intake. Environ. Sci. Pollut. Res. 22, 9595-9602.

Vrhovnik, P., Arrebola, J.P., Serafimovski, T., Dolenec, T., Šmuc, N.R., Dolenec, M., Mutch, E., 2013. Potentially toxic contamination of sediments, water and two animal species in Lake Kalimanci, FYR Macedonia: relevance to human health. Environ. Pollut. 180, 92-100.

Wang, W.X., 2002. Interactions of trace metals and different marine food chains. Mar. Ecol. Prog. Ser. 243, 295-309.

Watanabe, T., Kiron, V., Satoh, S., 1997. Trace minerals in fish nutrition. Aquaculture $151,185-207$.

Willis, J., Sunda, W., 1984. Relative contributions of food and water in the accumulation of zinc by two species of marine fish. Mar. Biol. 80, 273-279.

Wood, C.M., 2012. An introduction to metals in fish physiology and toxicology: Basic principles. In: Wood, C., Farell, A.P., Brauner, C. (Eds.), Fish Physiology: Homeostasis and Toxicalogy of Essential Metals, vol. 31A. Academic Press, San Diego, pp. :1-51.

Xu, Y., Wang, W.-X., 2002. Exposure and potential food chain transfer factor of Cd, Se and Zn in marine fish Lutjanus argentimaculatus. Mar. Ecol. Prog. Ser. 238, 173-186.

Zhang, W., Wang, W.-X., 2012. Large-scale spatial and interspecies differences in trace elements and stable isotopes in marine wild fish from Chinese waters. J. Hazard. Mater. 215, 65-74.

Zhao, X., Wang, W.-X., Yu, K., Lam, P.K., 2001. Biomagnification of radiocesium in a marine piscivorous fish. Mar. Ecol. Prog. Ser. 222, 227-237. 